\title{
Social Capital Framework for Iranian Audit Firms
}

\author{
Mohammadreza Mehrabanpour* \\ Assistant Prof. in Accounting, College of Farabi, University of Tehran. \\ (Corresponding Author), mehrabanpour@ut.ac.ir \\ Gholamreza Karami \\ Associate Prof. in Accounting, Faculty of Management, University of Tehran, \\ Tehran.ghkarami@ut.ac.ir \\ Mohammad Jandaghi Ghomi \\ Ph.D. Candidate in Accounting, College of Farabi, University of Tehran. Email: \\ jandaghighomim@gmail.com
}

\begin{abstract}
:
Audit firm faces complex issues such as conflict of interest, fierce competition, lack of intellectual capital, underdevelopment, and stakeholders' expectations gap. On the other hand, social capital is recognized as a fundamental solution to reconciling conflicts and strengthening trust, cooperation, synergy, and development. In this regard, the purpose of the present study is to explain the framework of social capital in the context of Iranian auditing firms. For this aim, the qualitative grounded theory method and a triangulation data collection including 25 semi-structured interviews, 38 secondary interviews, and the qualitative analysis of 548 documents from professional magazines of the country have been used in the present study. The results showed that the social capital of Iranian auditing firms can be explained from two perspectives, within the organization and outside the organization, and three structural, cognitive, and relational dimensions. In short, the structural dimension includes the organization, roles, and internal and external relations of the organization, the cognitive dimension includes the norms and policies of the organization's internal and external interactions, and the relationship dimension includes trust, intellectual capital, synergy, and legitimacy that is gained by the firm through the other two dimensions of income. Each dimension of the research framework explains several categories and contextual concepts that overall provide a comprehensive and coherent theoretical framework for the promotion and development of the country's auditing firms.
\end{abstract}

Keywords: Iranian audit firms, Social capital, Audit profession, Expectations gap, Stakeholders.

\section{Copyrights}

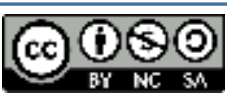

This license only allowing others to download your works and share them with others as long as they credit you, but they can't change them in any way or use them commercial. 


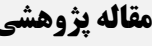

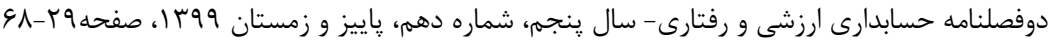

\section{جار جوب سر مايه اجتماعى براى مؤسسات حسابرسى ايران

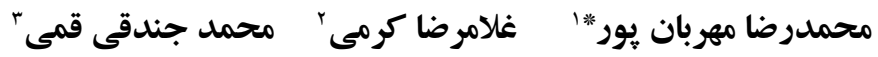

تاريخ يذيرش: 99//r/F

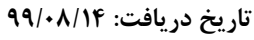

جكکبه

مؤسسه حسابرسى با مسائل يِيجيدهاى از قبيل تضاد منافع، رقابت حاد، كمبود سرمايه فكرى، توسعهنيافتخى و فاصله انتظارهاى ذينفعان مواجه است. از سوى ديگر، سرمايه اجتماعى به عنوان راهحلى بنيادين براى ايجاد مصالحه در تضادها و تقويت اعتماد، تعاون، همافزايى و توسعه شناخته

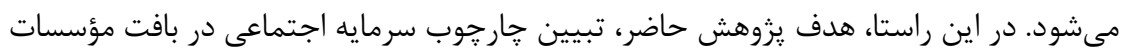

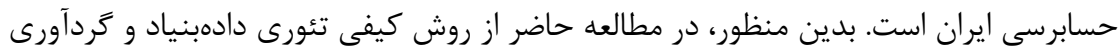

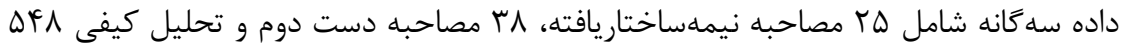

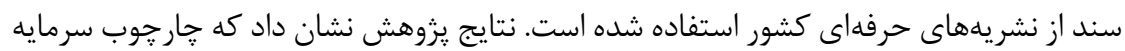
اجتماعى مؤسسات حسابرسى ايران از دو منظر درونسازمانى و برونسازمانى و سه بُعد ساختارى، شناختى و رابطهاى قابل تبيين مىباشد. بلهور خلاصه، بُعد ساختارى شامل تشكيلات، نقشها و روابط درونى و بيرونى مؤسسه، بُعد شناختى شامل هنجارها و سياستهاى مؤسسه در تعاملهاى درونى و بيرونى، و بُعد رابطهاى شامل اعتماد، سرمايه فكرى، همافزايى و مشروعيتى است

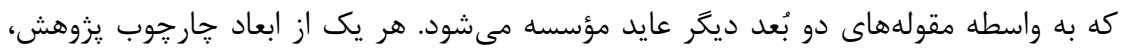
مقولهها و مفاهيم زمينهاى متعددى را تبيين مى كنند كه در مجموع، يك سازه تئوريك جامع و

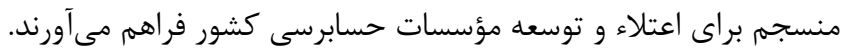
وازگَان كليدى: مؤسسات حسابرسى ايران، سرمايه اجتماعى، حرفه حسابرسى، فاصله انتظارها، ذينفعان.

' استاديار حسابدارى، يرديس فارابى دانشعاه تهران. (نويسنده مسئول) ، mehrabanpour@ut.ac.ir rادانشيار حسابدارى، دانشكده مديريت دانشعاه تهران (ghkarami@ut.ac.ir) ץ دانشجوى دكترى حسابدارى، يرديس فارابى دانشخاه تهران (jandaghighomim@gmail.com) 
مؤسسه حسابرسى يك نهاد اجتماعى پِيجيده است كه اجتماعى منحصر به فرد از انكَيزها،

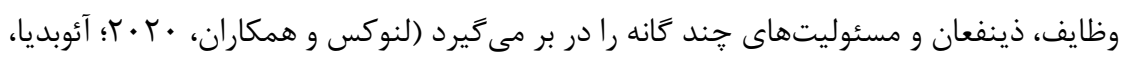

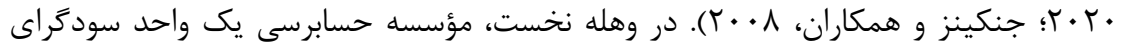

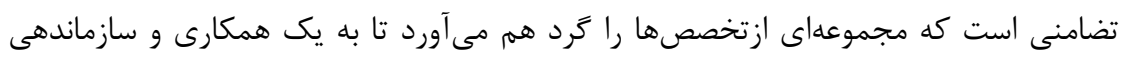

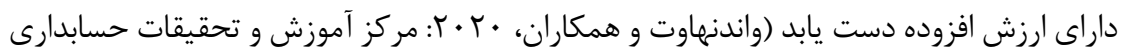

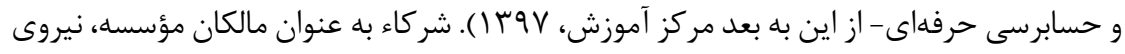

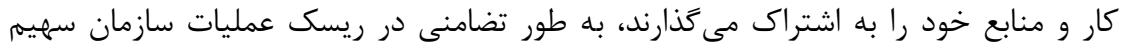

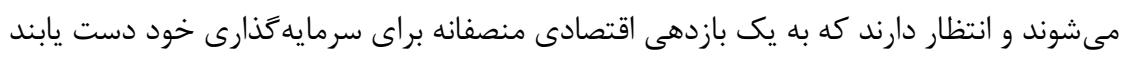

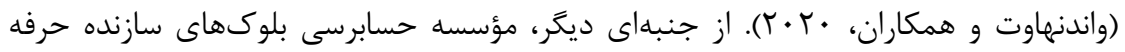

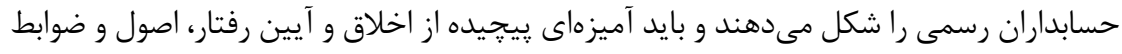

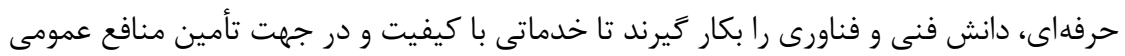

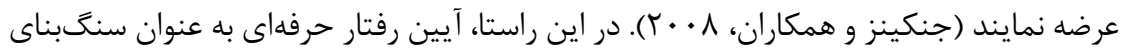

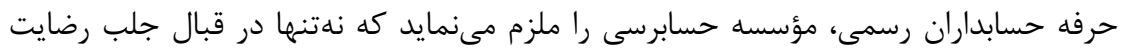

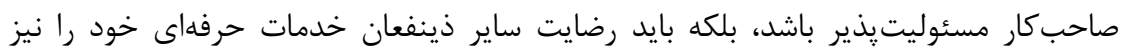

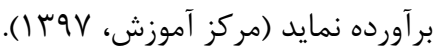
بنابر توصيف فوق از مؤسسه حسابرسى، ير واضح است كه يك مؤسسه حسابرسى با مسائل

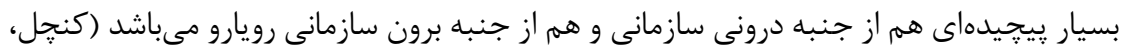

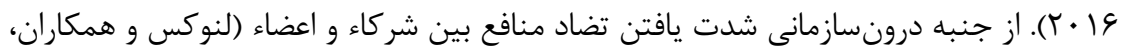

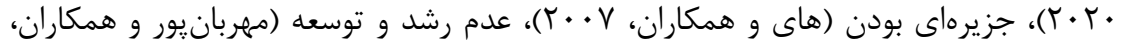

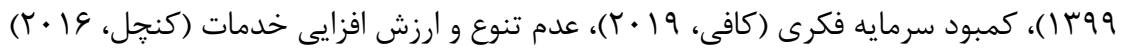

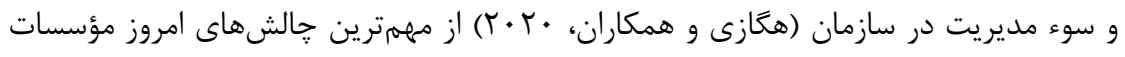

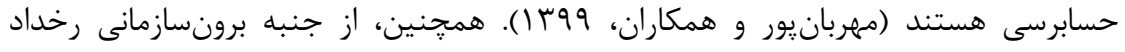

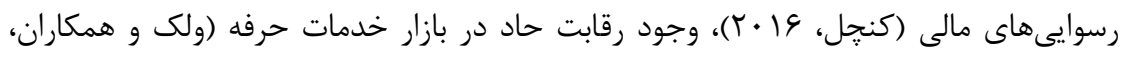

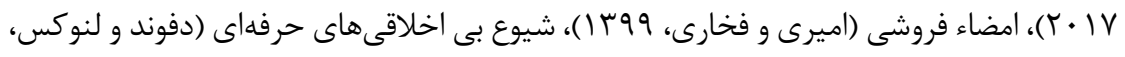

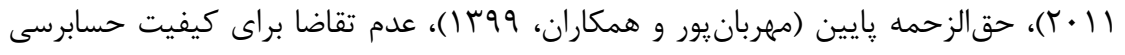

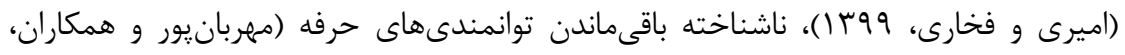

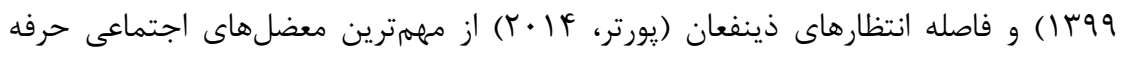
حسابرسى به شمار مى آيند. 
در يزوهش هاى معاصر علوم اجتماعى سرمايه اجتماعى' به عنوان يك راهحل جامع و تحول

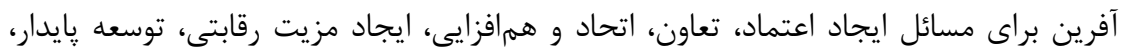

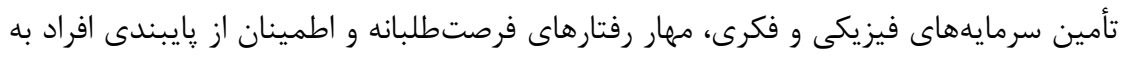

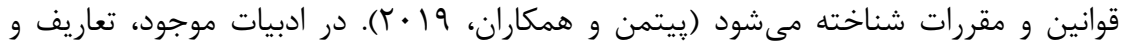

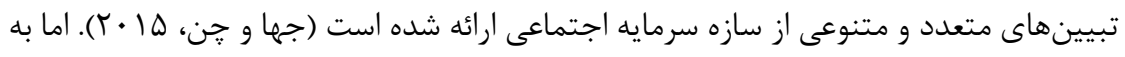

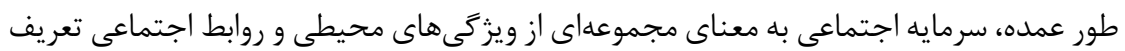

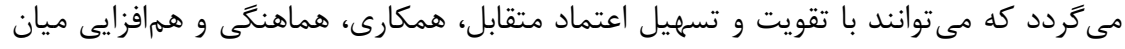

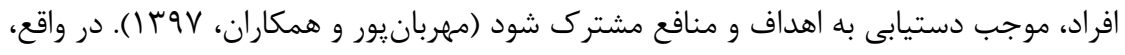

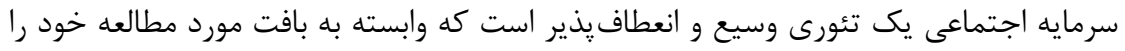

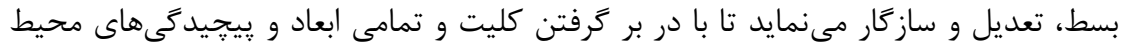

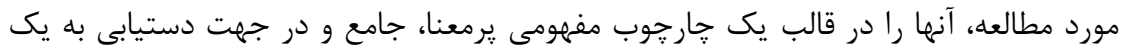

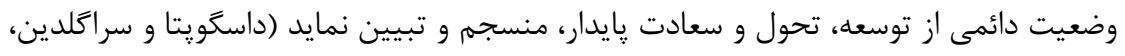

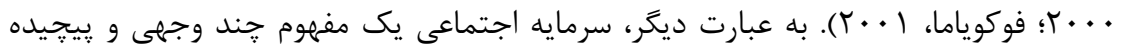

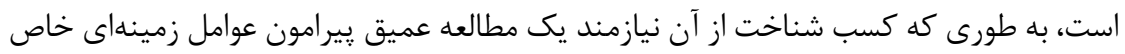

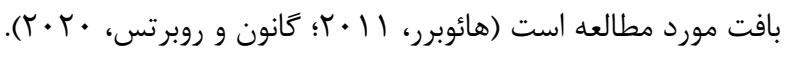

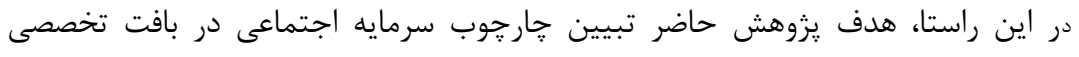

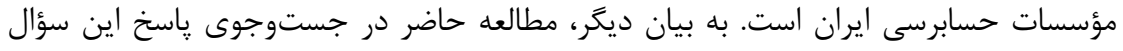

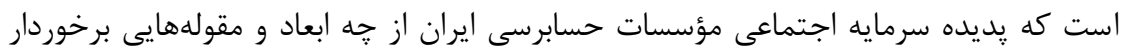

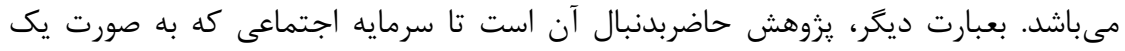

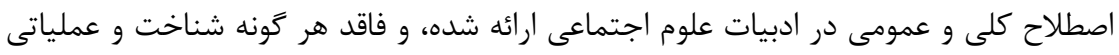

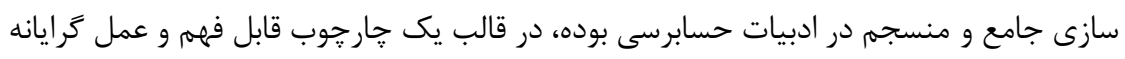

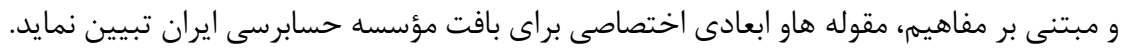

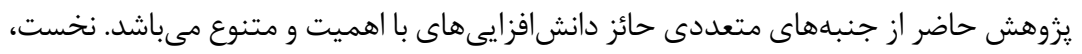

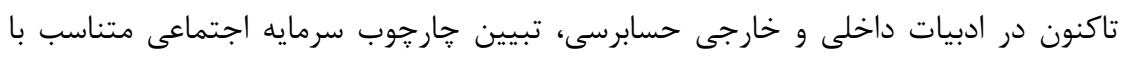

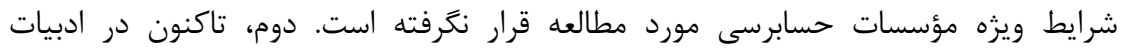

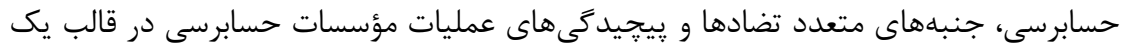

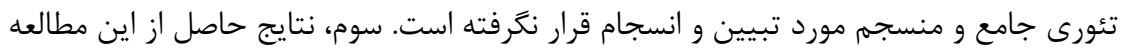

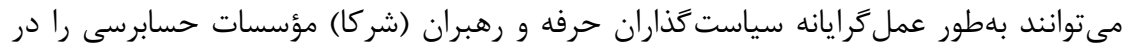

${ }^{1}$ Social capital theory 
جهت مديريت زمينههاى بنيادين ارتقاى كيفيت و توسعه پايدار خدمات حرفهاى حسابداران

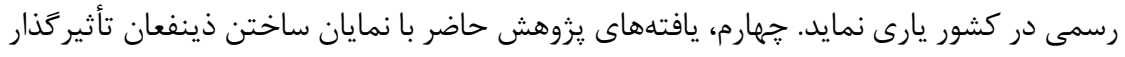

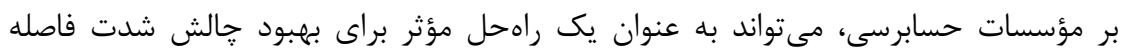

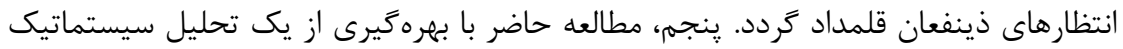
ميدانى، مقولهها و مفاهيم رفتارى متعددى ييرامون سرمايه اجتماعى مؤسسات حسابرسى نمايان

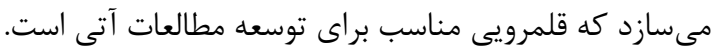

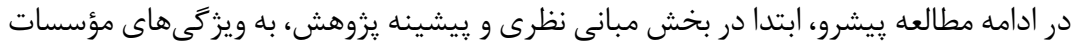

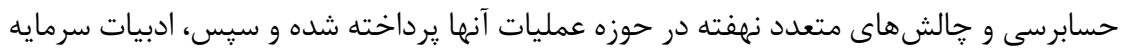

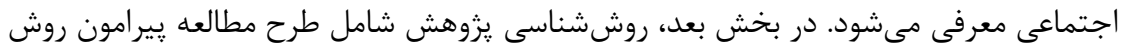

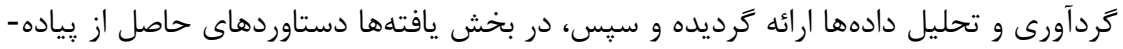
سازى تئورى سرمايه اجتماعى در بافت تخصصى مؤسسات حسابرسى ايران تبيين مى شیود.

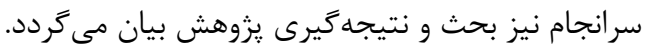

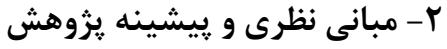

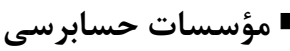

مؤسسات حسابرسى ستون فقرات و تأمين كنندكان اصلى خدمات حرفه حسابدارى به جامعه

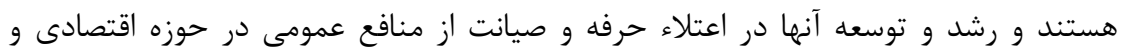

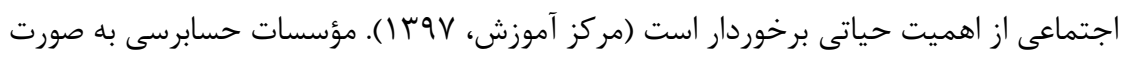
واحدهاى انتفاعى تضامنى و در جار جوب قوانين و مقررات حرفه فعاليت مى كنند. شر كاء مؤسسه

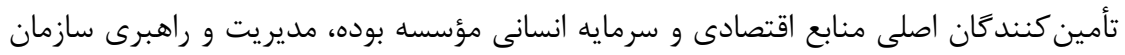

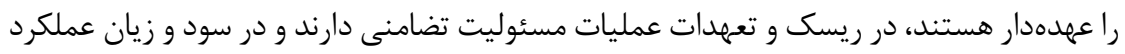

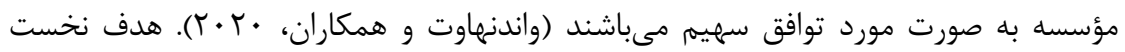

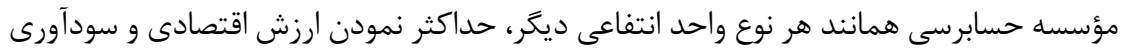

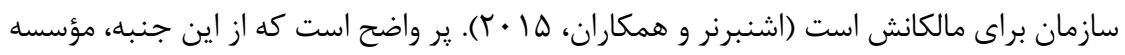

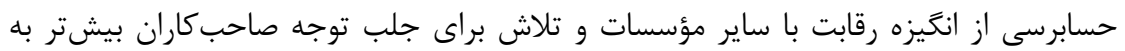

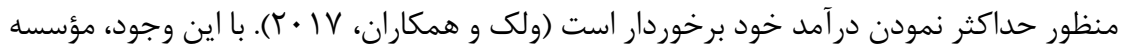

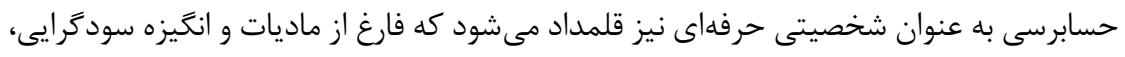

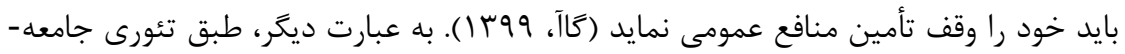

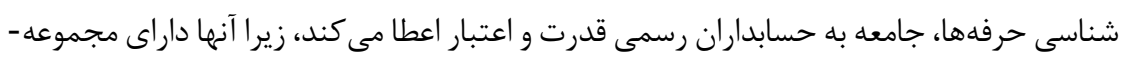

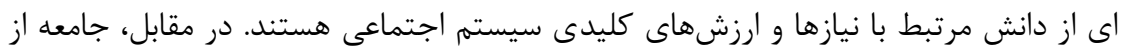


حرفه انتظار دارد كه در ارائه خدمات خود، به تأمين منافع عمومى در برابر منافع مادى خود

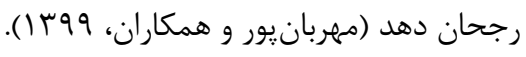

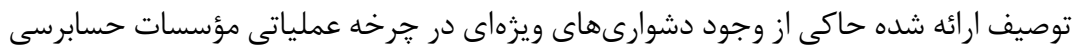

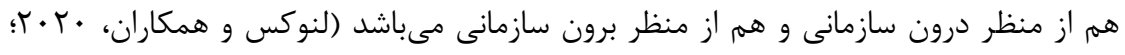

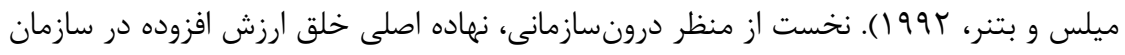

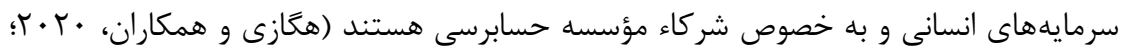

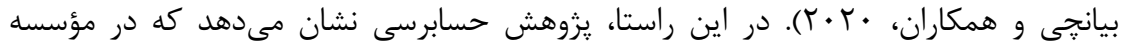

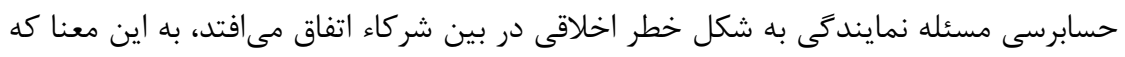

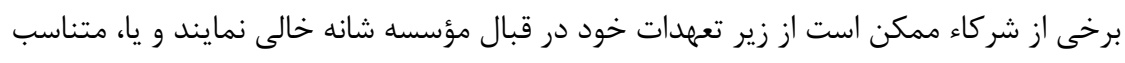

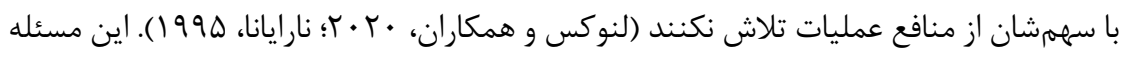

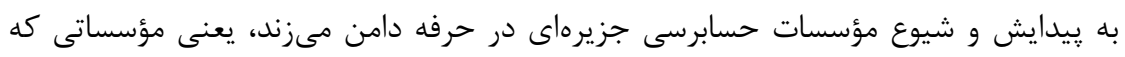

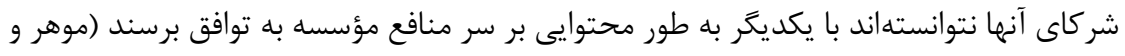

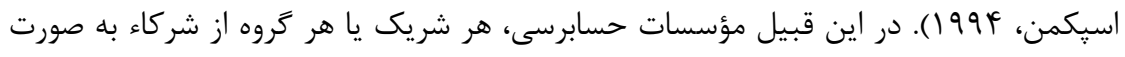

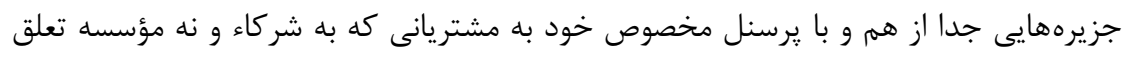

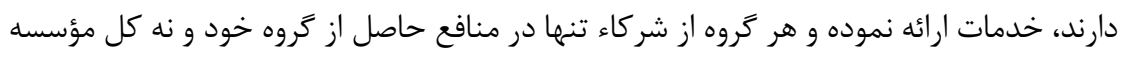

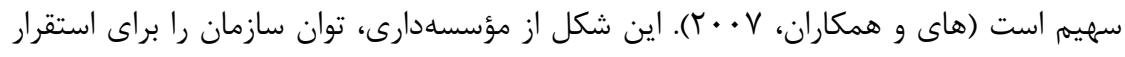

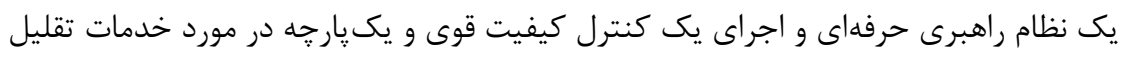

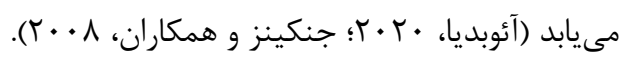

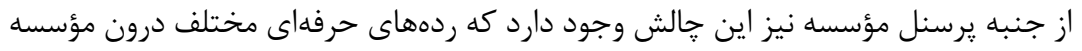

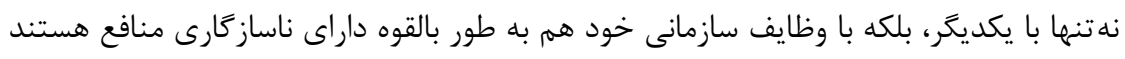

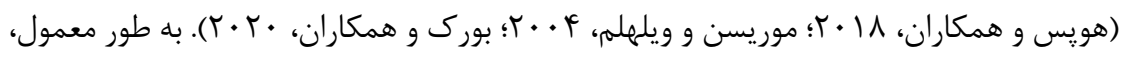

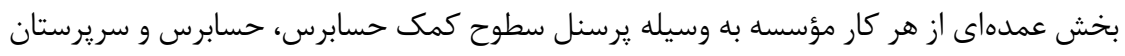

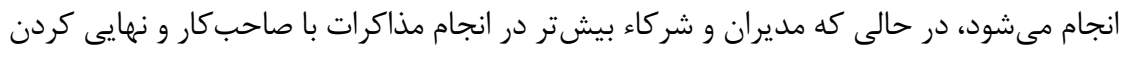

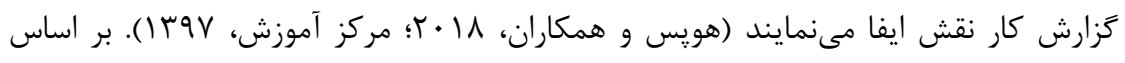

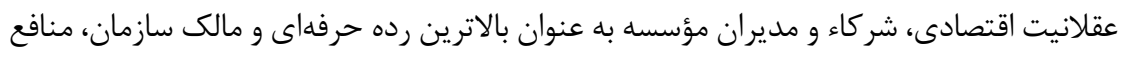

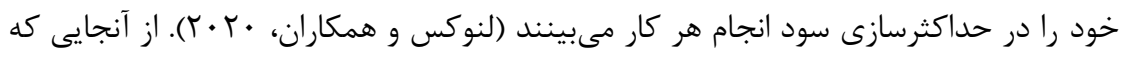

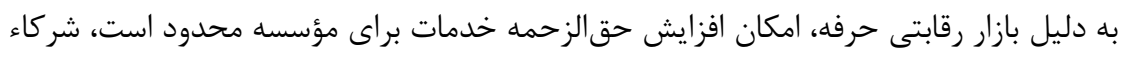

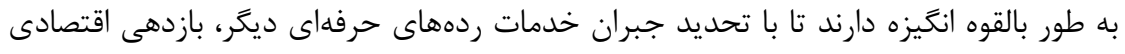

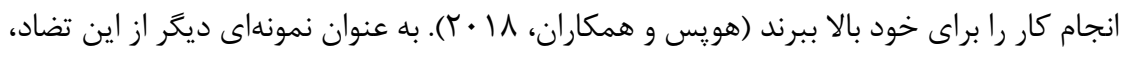

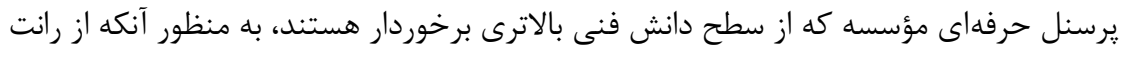


برترى فنى خود مراقبت نمايند، به طور عقلايى از اين انخيزه برخوردار هستند كه از تعليم و

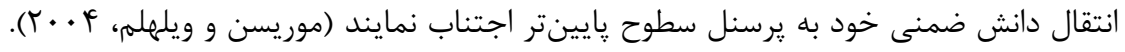

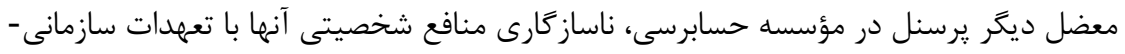

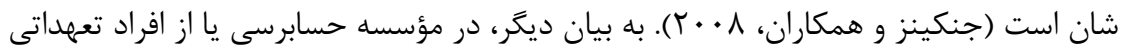

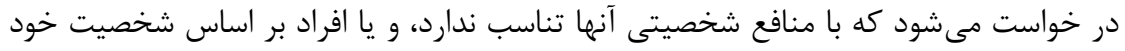
منافعى از سازمان انتظار دارند كه در مؤسسه تعهدى براى برآورده كردن آنها آنها

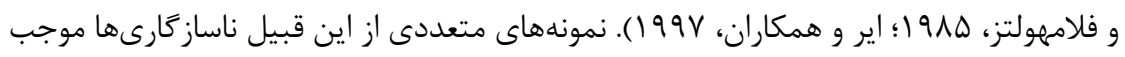

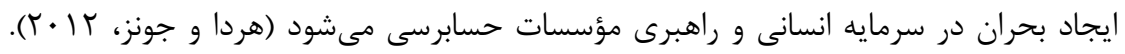

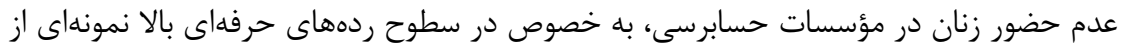

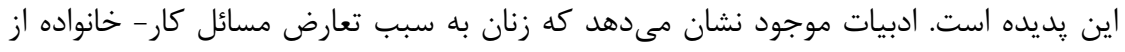

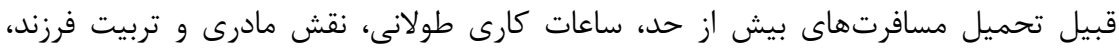

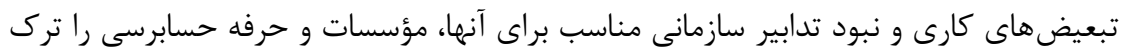

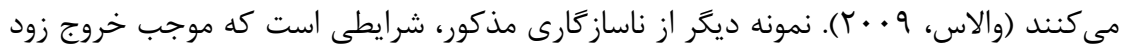

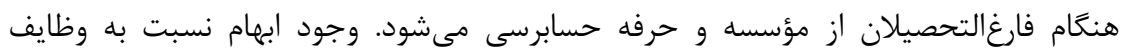

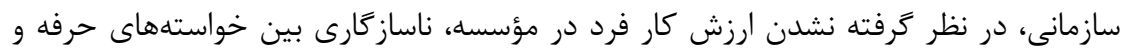

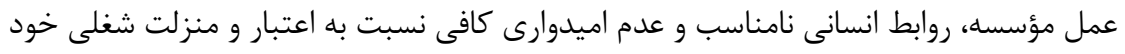

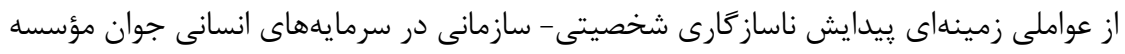

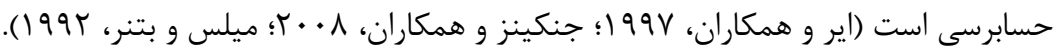

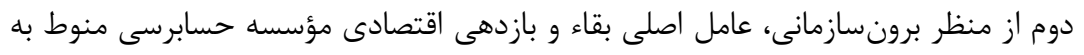

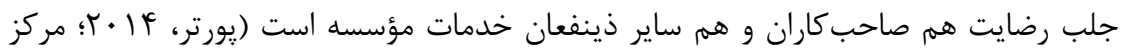

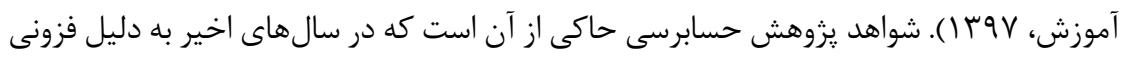

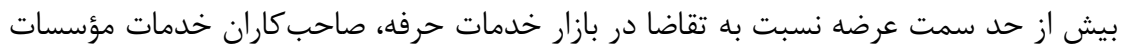

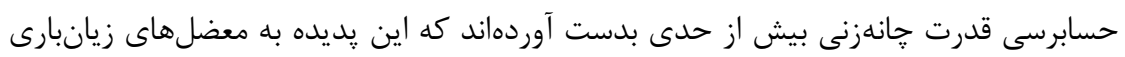

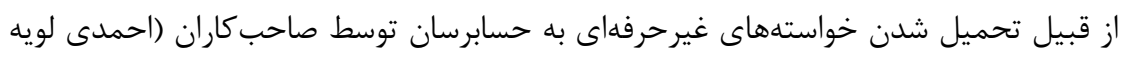

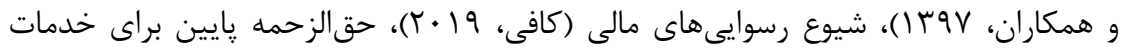

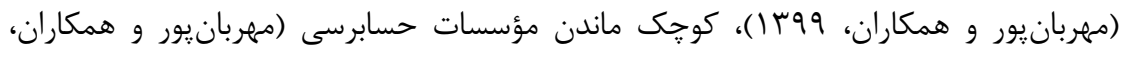

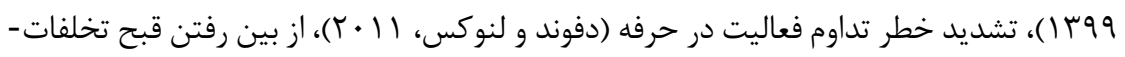

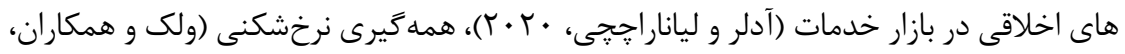

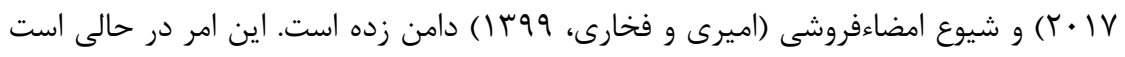

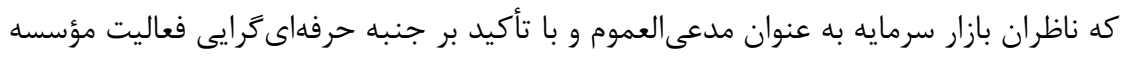


حسابرسى، همجنان به طور پِيوسته خواهان رقابت بيشتر در بازار حرفه، كيفيت بالاتر خدمات

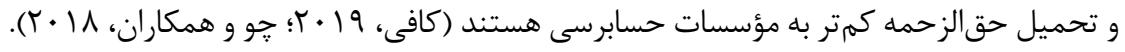

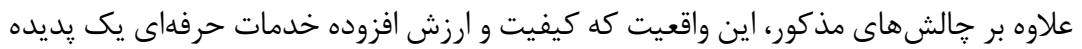

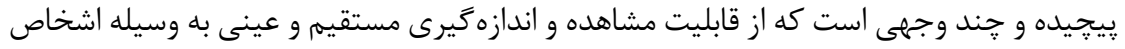

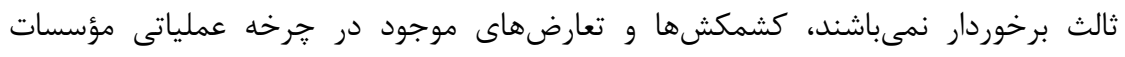

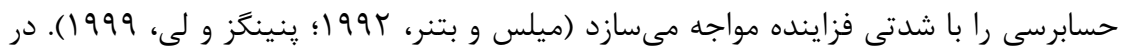

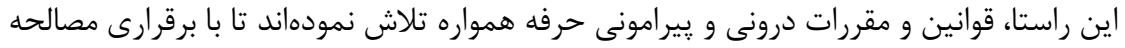

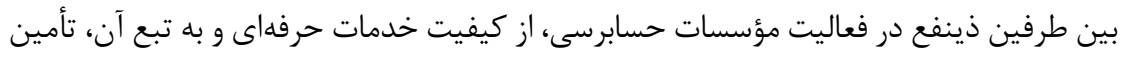

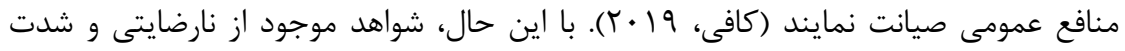

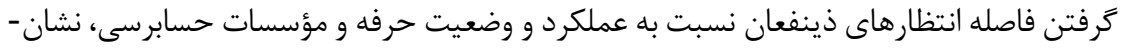

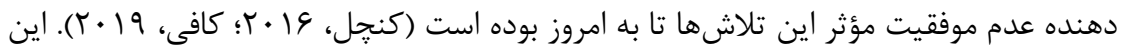

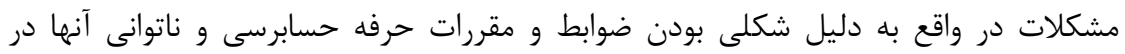

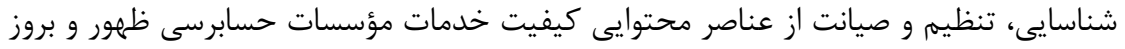

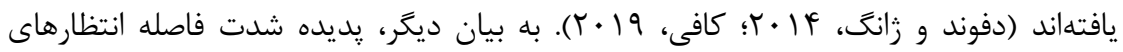

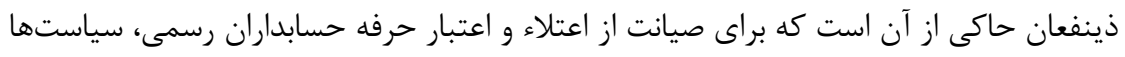

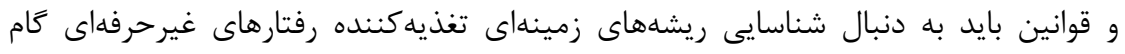

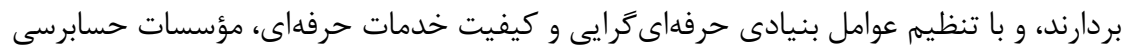

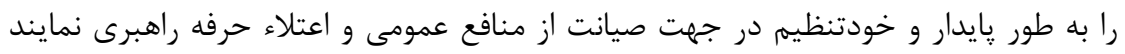

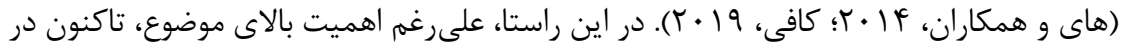

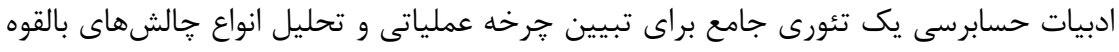

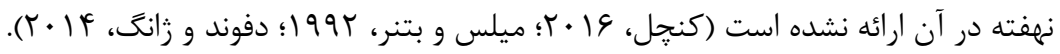

\section{• سر مايه اجتماعى براى مؤسسات حسابرسى}

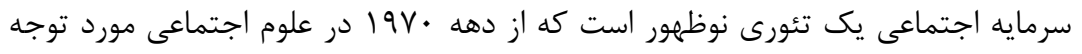

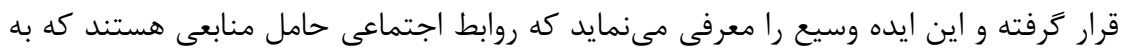

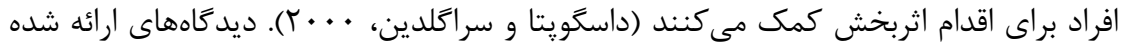

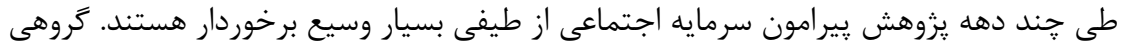

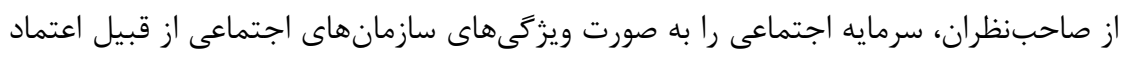

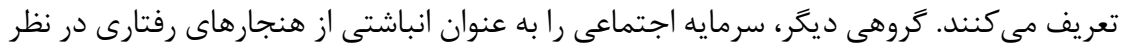

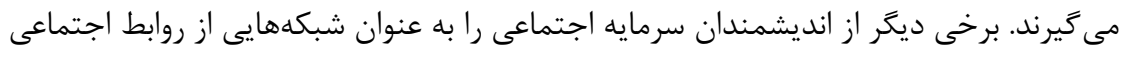


تبيين ميىمايند و عدهاى ديگر نيز، يك منظومه تركيبى از ديدگاههاى مذكور را عرضه مىنمايند

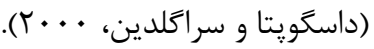

در اين راستا، ناهاييت و قوشال (991 (191) سرمايه اجتماعى را به سه نوع ساختارى، شناختى و رابطهاى دستهبندى مى كند. سرمايه ساختارى الكويى كلى از اتصالها بين كنشگران است، يعنى كسانى كه افراد به آنها دسترسى دارند و اينكه جُخونه به آنها دسترسى مى يابند. در واقع،

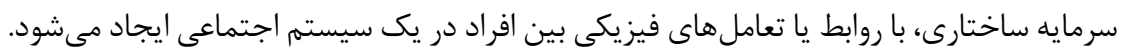
سرمايه اجتماعى ساختارى، اشكال مختلفى از سازمان اجتماعى و بهطور خاص نقشها، قواعد، سوابق، رويهها و نيز انواع مختلفى از شبكه روابط را در بر مى خيرد كه به ايجاد همكارىها و بخصوص تلاش براى انجام اقدامهاى جمعى داراى منافع مشترك كمك مئنمايد (داسگويتا و

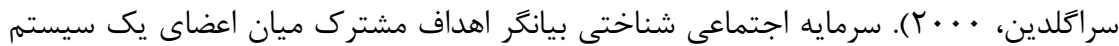

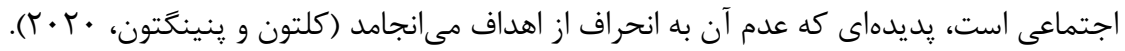
در واقع، منظر شناختى سرمايه اجتماعى ناشى از فرآيندهاى ذهنى افراد بوده و ايدههاى تحميل

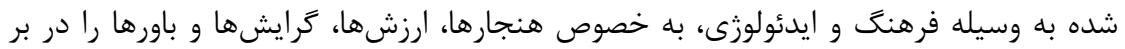
مى گيرد كه به ايجاد رفتارهاى تعاونى و اقدام جمعى براى منافع مشترك كمك مىنمايد

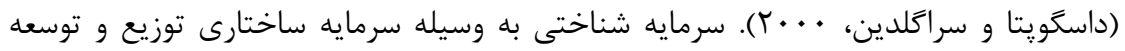
مى يابد و نشان مى دهد كه تا جهه ميزان اعضاى شبكه از درك و رويكردى مشترك براى ايفاى به

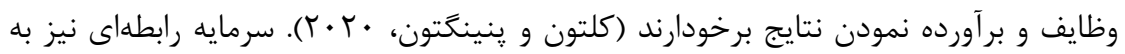

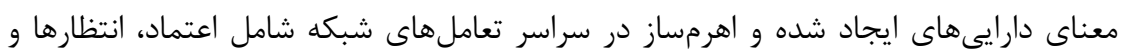
تعردات است. سرمايه رابطهاى به وسيله هر دو سرمايههاى ساختارى و شناختى تحت تأثير قرار مى گيرد و منابع رابطهاى تعبيه شده در شبكه اجتماعى را بازتاب مى دهد (كلتون و گينينگتون،

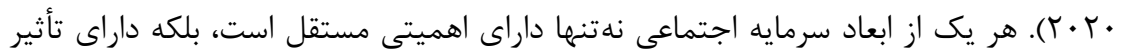

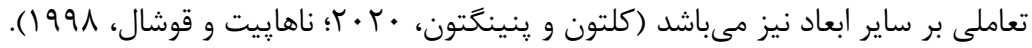
از ديدكاهى ديگر، يوتنام با تمركز بر يك ايده درونى و بيرونى از سرمايه اجتماعى، دو نوع

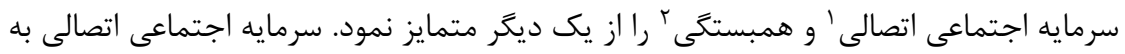
معناى گرد هم آوردن افرادى بسيار متفاوت، و سرمايه اجتماعى همبستگى به معناى ايجاد ارتباط بين افراد مشابه مىباشند. به بيانى ديخر، سرمايه اجتماعى اتصالى، به افراد خارج از يكى گروه

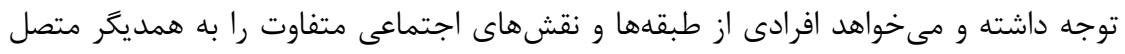
نمايد. در مقابل، سرمايه اجتماعى همبستكى، خواهان ايجاد اتحاد و انسجام در بين گروههايى

${ }^{1}$ Bridging social capital

${ }^{2}$ Bonding social capital 


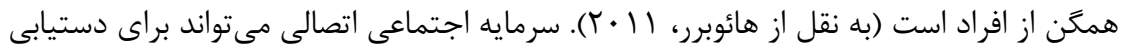

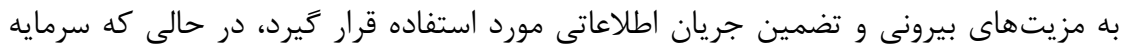

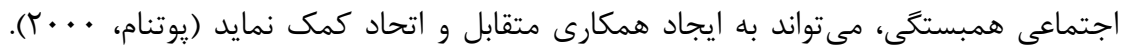

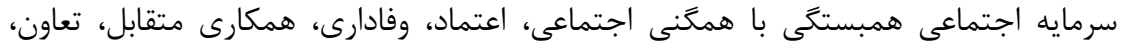

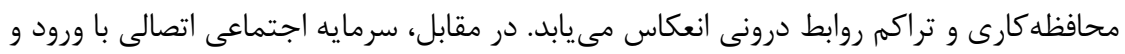

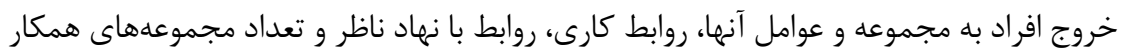

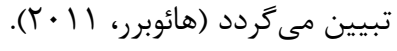

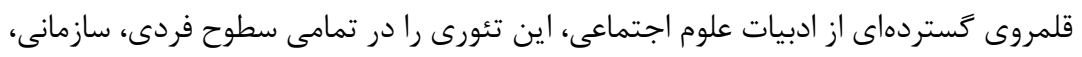

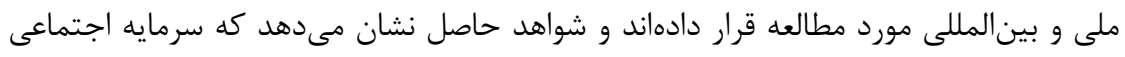

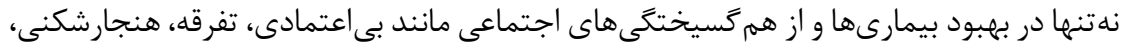

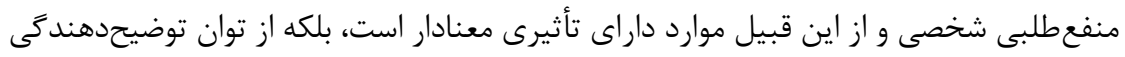

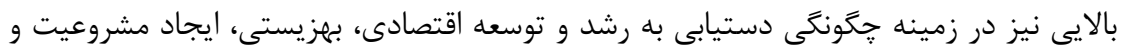

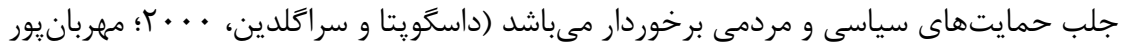

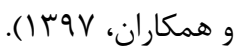

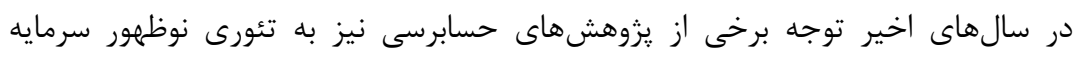

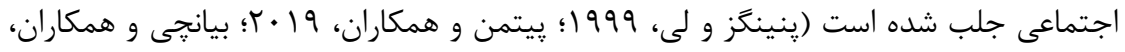

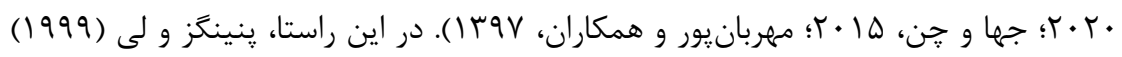

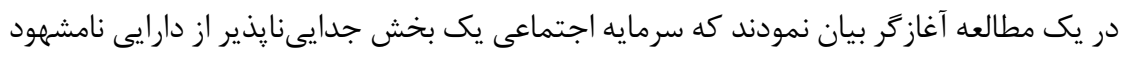

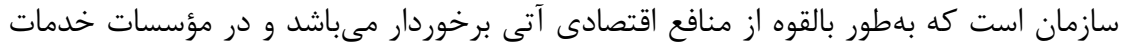

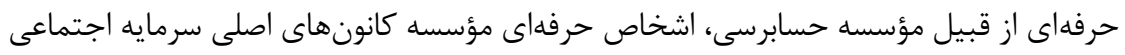

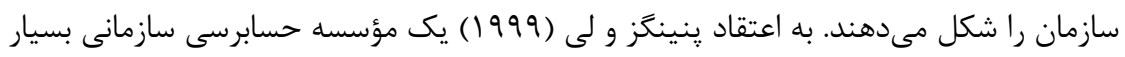

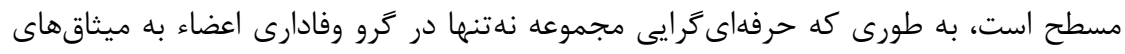

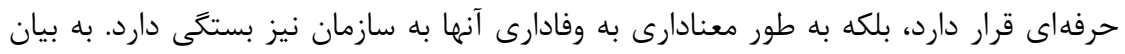

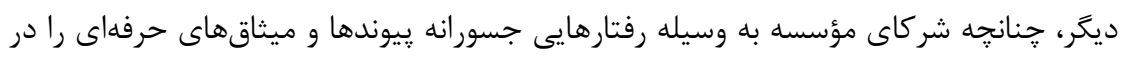

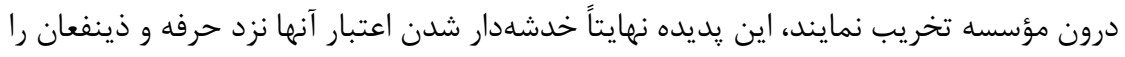

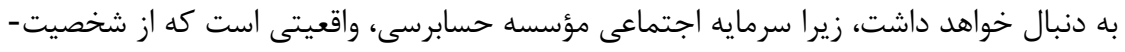

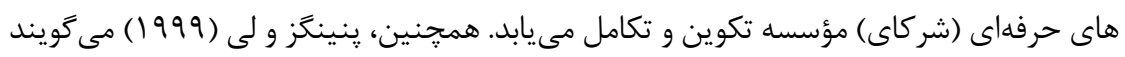

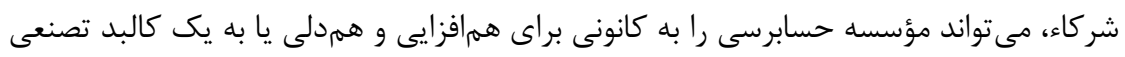

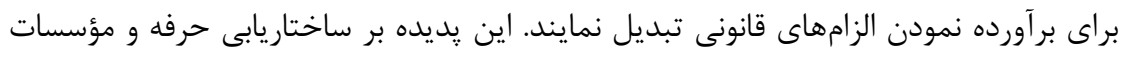

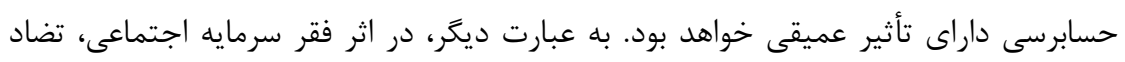


منافع و ناسازكارىها در مؤسسات حسابرسى شدت مىيابند و نتيجه اين امر شكسته شدن يا

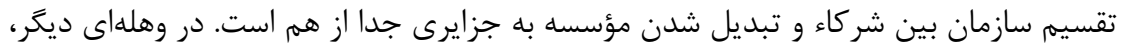

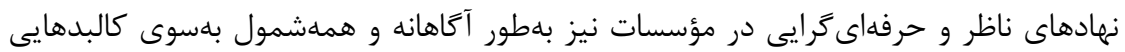
غيراثربخش و ظاهرى سوق مى يابند و هر كسى هم كه وارد بافت حرفه حسابرسى شود، ناكزير است شرايط تصنعى حاكم را بيذيرد.

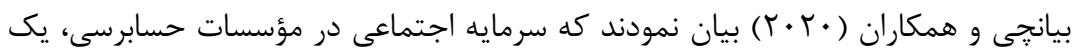

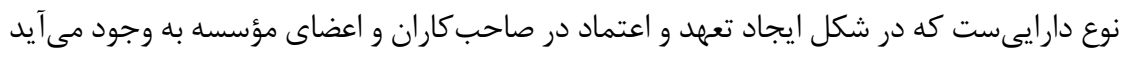

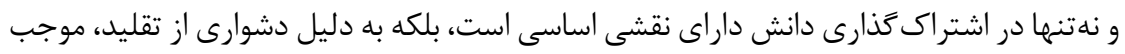

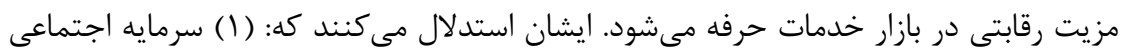

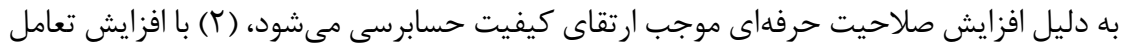

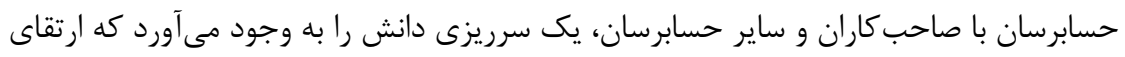

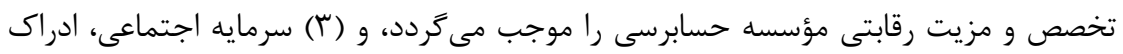

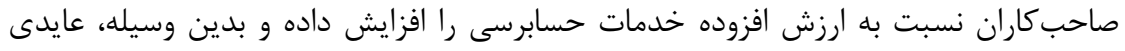

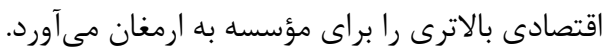

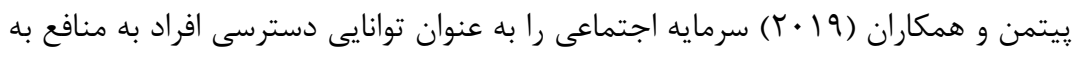
وسيله روابط تعريف مى كنند و استدلال نمودند كه سرمايه اجتماعى عملكرد و آينده كارى

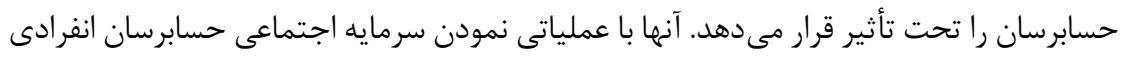

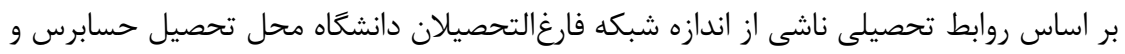

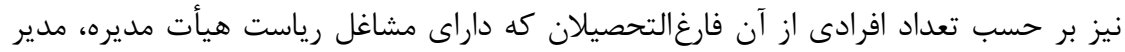

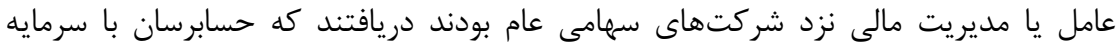

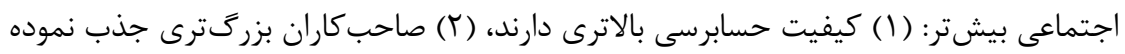

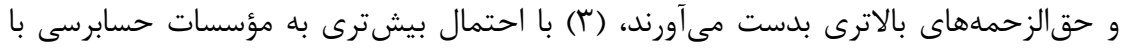

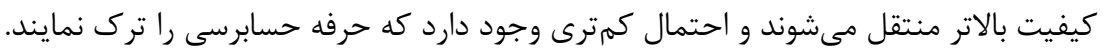

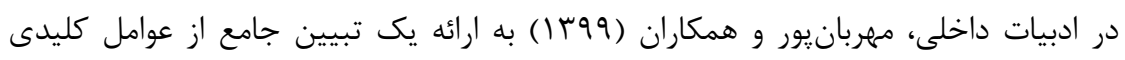

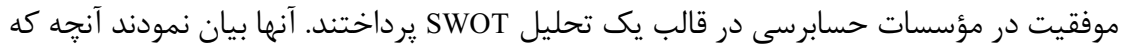

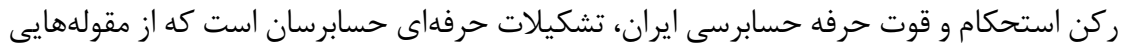

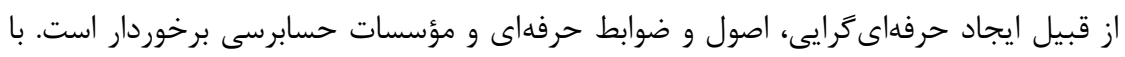

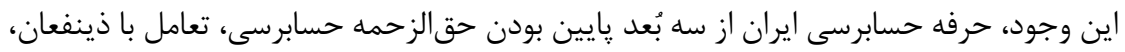

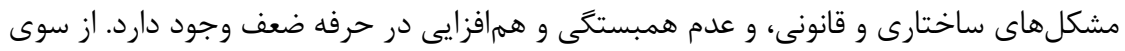

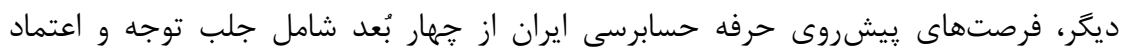


ذينفعان، توسعه روابط بينالمللى، بزرگتر شدن مؤسسات حسابرسى، و تجديد ساختار در اركان

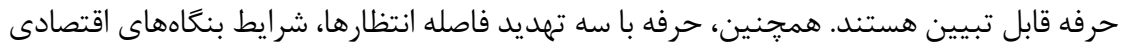

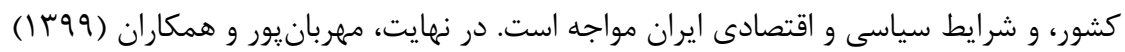

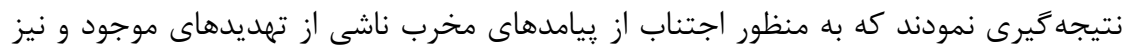

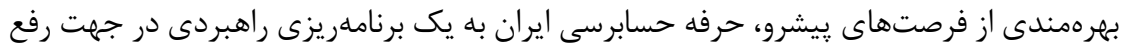
ضعفها و افزايش بهر مورى نقاط قوت خود نيازمند است. همجنين، در يزوهشهاى حسابرسى كه در آنهاب طور خلاصه به تئورى هاى مربوط به سرمايه

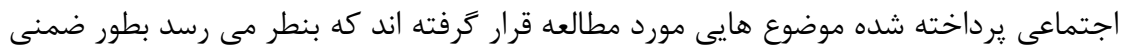

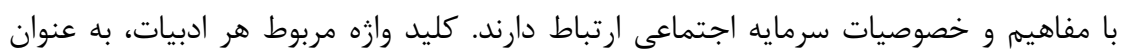
مضمون برجسته شده و در جدول ا آورده شده است.

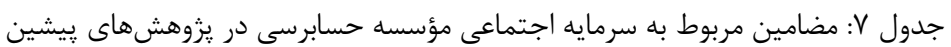

\begin{tabular}{|c|c|}
\hline مضامين ادبيات & موضوعها \\
\hline 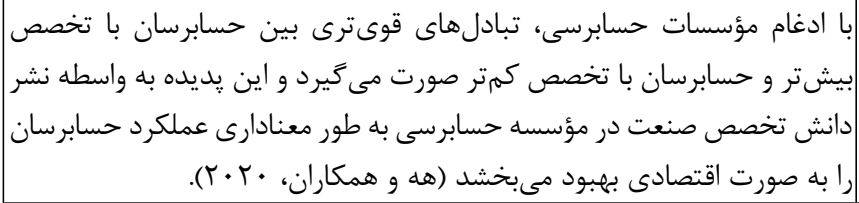 & ادغام \\
\hline 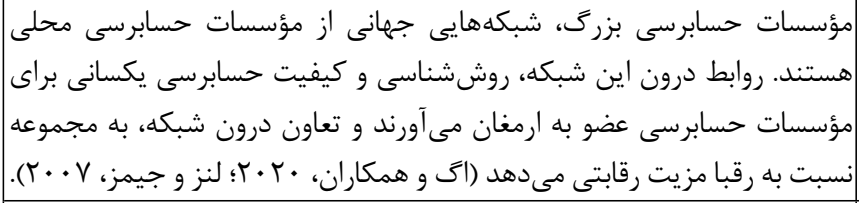 & مؤسسات حسابرسى \\
\hline 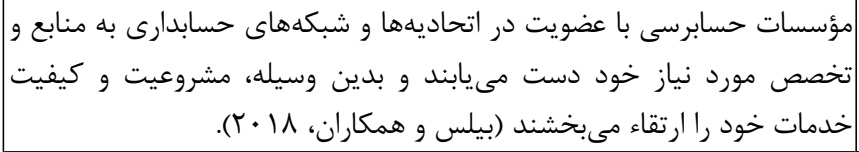 & 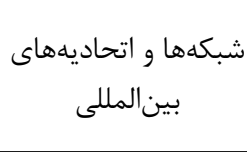 \\
\hline 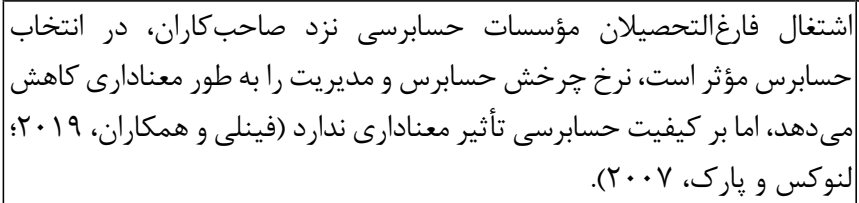 & فارغالتحصيلان \\
\hline 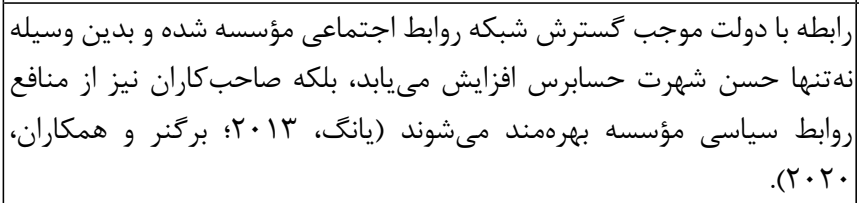 & روابط سياسى \\
\hline 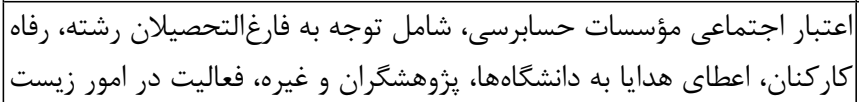 & مسئوليتيذيرى \\
\hline
\end{tabular}




\begin{tabular}{|c|c|}
\hline 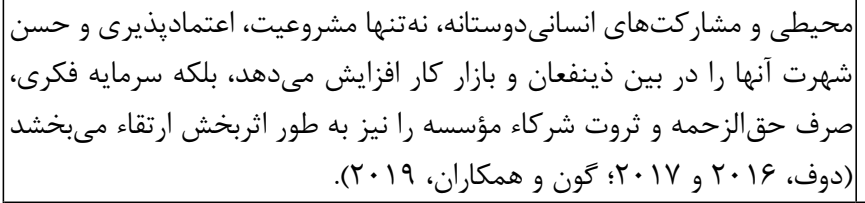 & \\
\hline 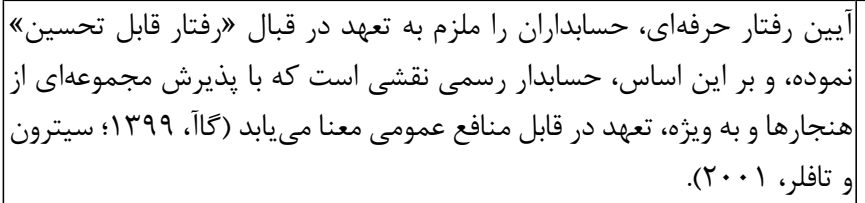 & آيين رفتار حرفهاى \\
\hline 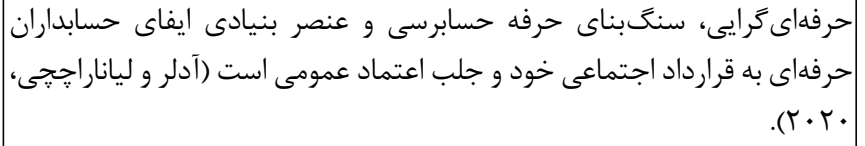 & |حرفه| \\
\hline 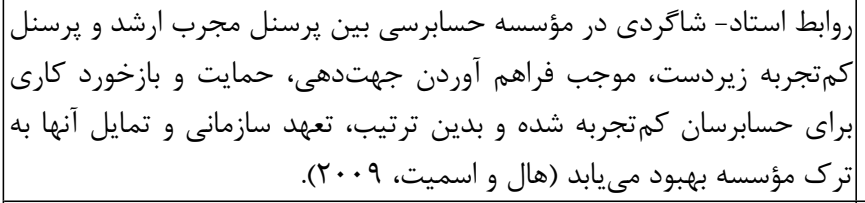 & روابط استاد- شاكردى \\
\hline 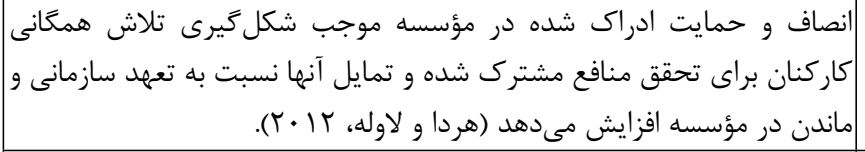 & روابط مؤسسه- \\
\hline 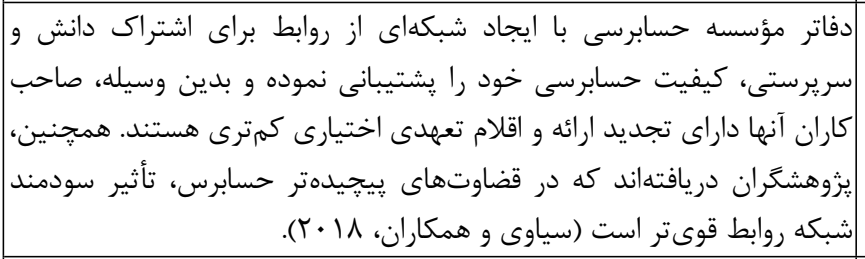 & شبكه روابط درون \\
\hline 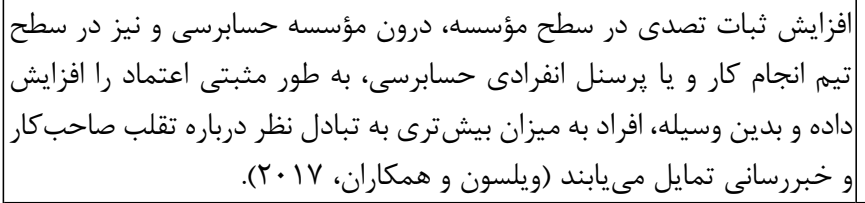 & حبات مؤسسه \\
\hline 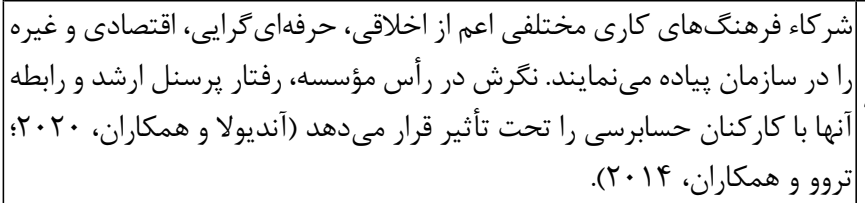 & نكرش در رأس مؤسسه \\
\hline 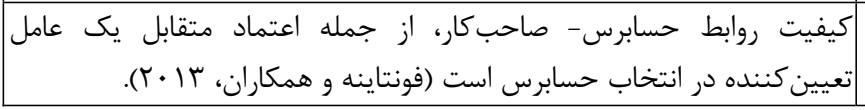 & روابط حسابرس- \\
\hline
\end{tabular}


ادبيات سرمايه اجتماعى به روشنى نشان مىدهند كه اين مفهوم، يك سازه يِيجيده، جند

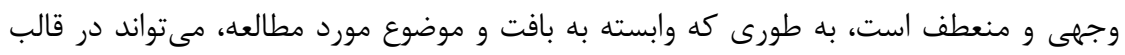

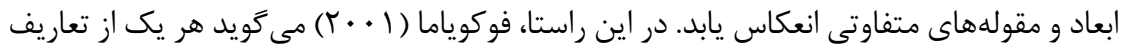

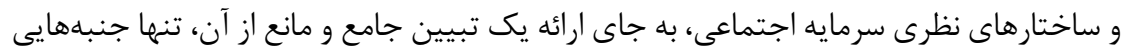

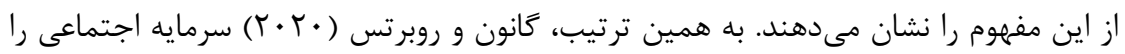

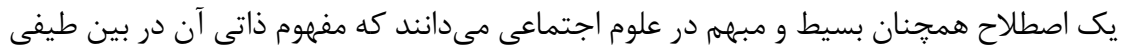

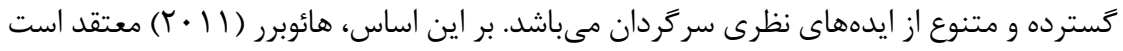

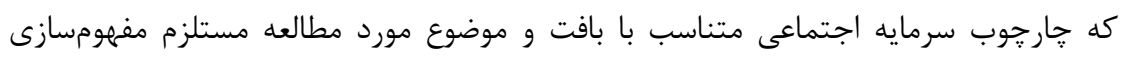
اختصاصى و دقيق است، زيرا در غير اينصورت، سرمايه اجتماعى يك سازهاى ساختار نيافته

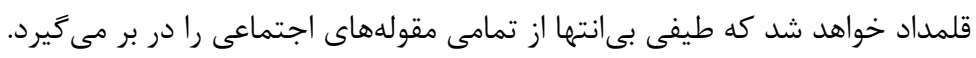
از سوى ديگر، همانطور كه از مبانى نظرى و پيشينه يزّوهش قابل استنباط است، مؤسسات

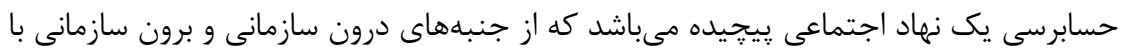
جالشهاى متعدد و متنوعى در خرخه عملياتى خود مواجه است. از طرف ديخر، تاكنون يك تئورى جامع در ادبيات حسابرسى براى تبيين منسجم جالشهاى مذكور ارائه نشده و به تبع اين امر، سياستها و قوانين حرفه هم در راهبرى مؤسسات و حرفه حسابرسى در مسير اعتلاء و توسعه موفقيت جندانى حاصل نكردهاند. با اين وجود، سرمايه اجتماعى داراى يك ساختار نظرى هـ منعطف و تطبيقيذير است كه براى تبيين عناصر بنيادى جامعهشناختى و ايجاد مصالحه بين آنها كاربرد داشته و مىتواند با انجام يك تحليل سيستماتيك مبتنى بر عناصر زمينهاى نهاد اجتماعى مورد نظر، جار جوبى جامع، منسجمم و مؤثر براى ايجاد اعتماد متقابل، تعاون، هممافزايى

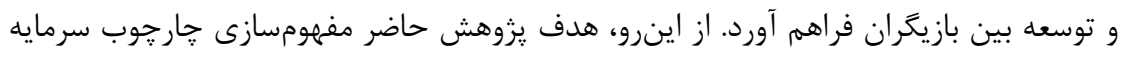
اجتماعى در بافت مؤسسات حسابرسى ايران است، بهطورى كه راهحلى جامع و منسجم برى براى ياسخ گويى به جالشهاى درونى و بيرونى مؤسسات حسابرسى فراهم آيد. به بيانى ديخر، يزوهش

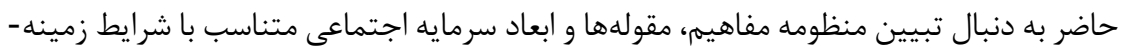

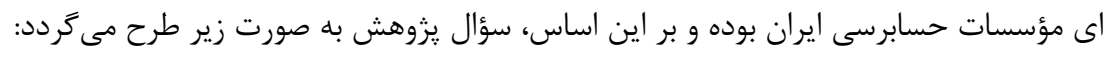

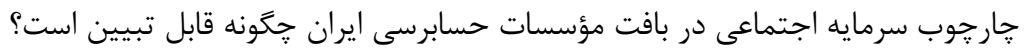

\section{F- روششناسى يزوهش}

يزوهش حاضر مطالعهاى كيفى و اكتشافى به روش تئورى دادهبنياد است. در اين راستا،

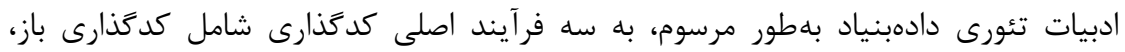

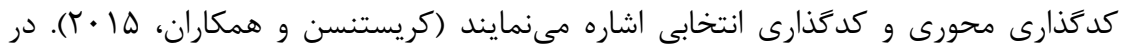


كد كذارى باز، اجزاى داده يزوهش از هم ديكر باز شده و به مفاهيمى اوليه و موقت تجزيه مىشوند.

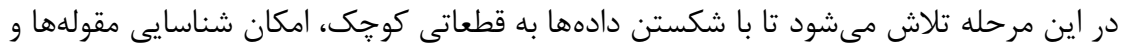

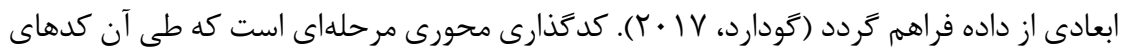
باز بر حسب خصوصياتشان با يكديكر تلفيق مىشوند تا مقولههايى غنى تر از مفاهيم اوليه ساخته

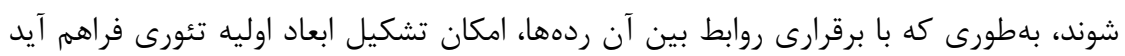

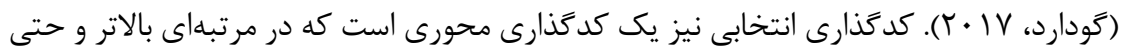

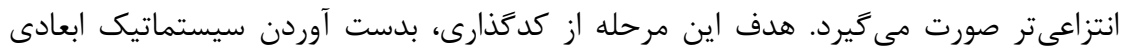

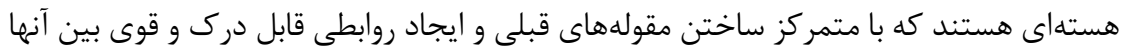

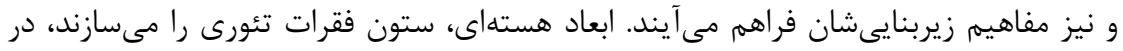

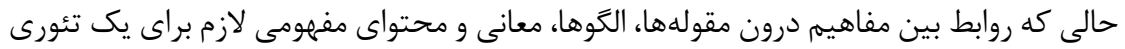

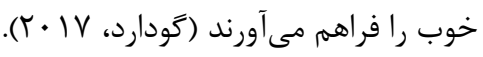

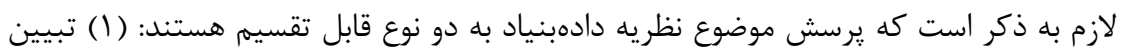

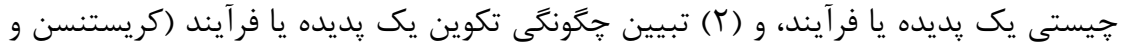

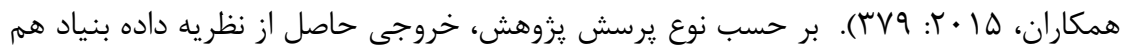

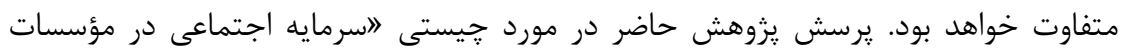

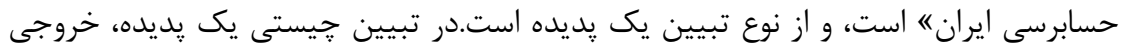

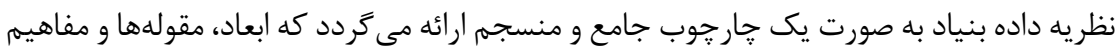

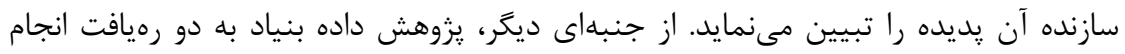

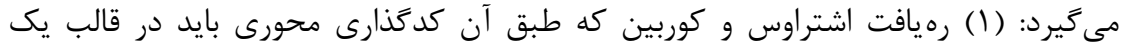

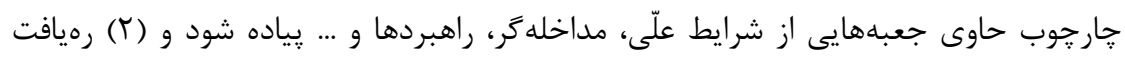

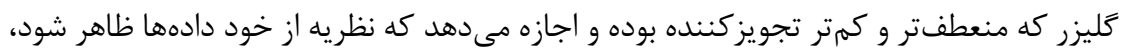

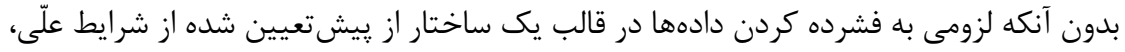

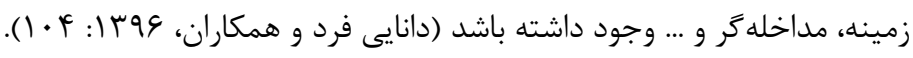

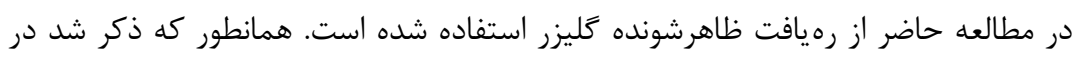

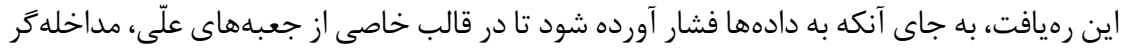

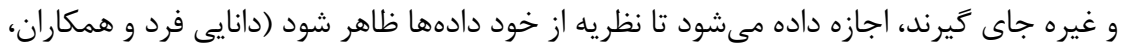

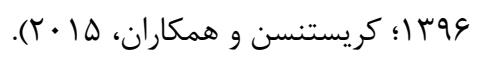

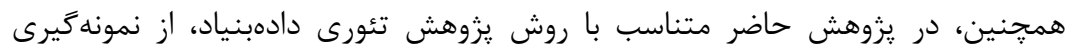

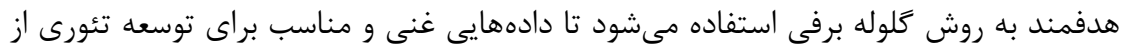

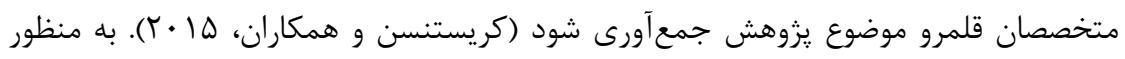


تعيين اندازه نمونه يزوهش نيز از قاعده اشباع نظرى استفاده مى خردد. به عبارت ديكر، فرآيند

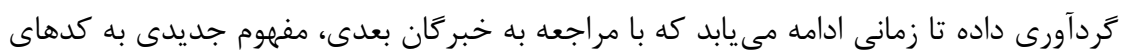

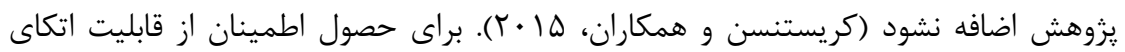

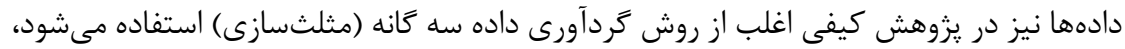

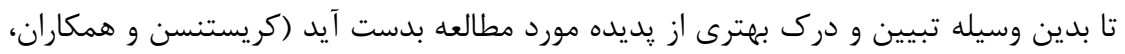

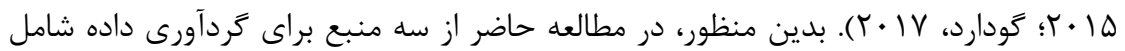

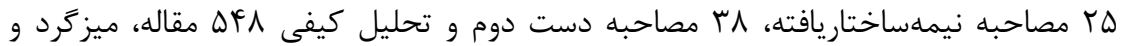

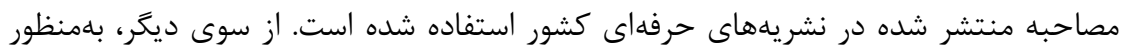

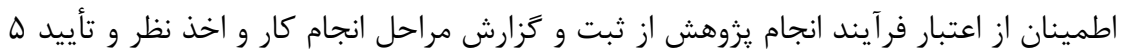

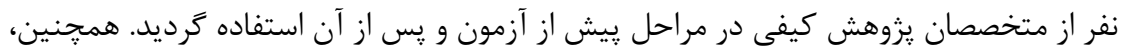

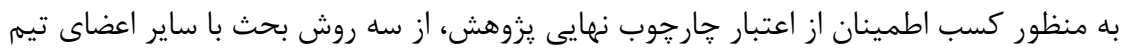

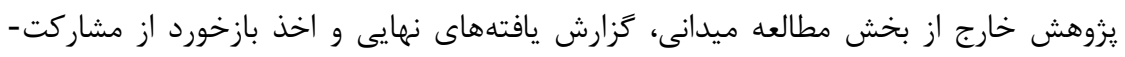

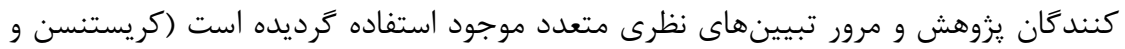

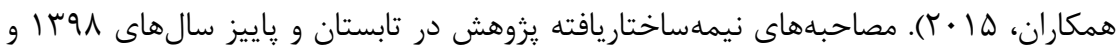

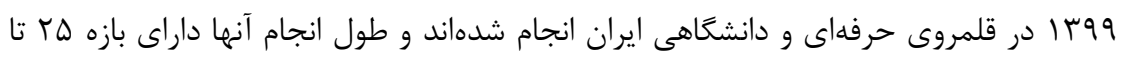

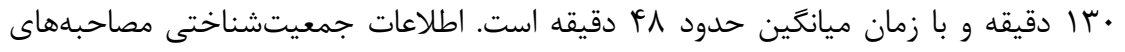

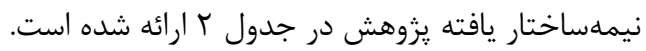

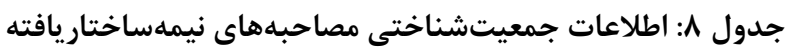

\begin{tabular}{|c|c|c|c|c|c|c|}
\hline . 19 سال 19 & • • & 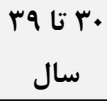 & يا بيشتر & جمع & سوابق حرفهاى / دانشكاهى & |شناسه \\
\hline - & 1 & 1 & 1 & r & |رضو شوراى عالى جامعه حسابداران & | 1-الف \\
\hline$r$ & 1 & f & - & V & شريك مؤسسه حسابرسى & | r-الف \\
\hline$\cdot$ & 1 & 1 & $\cdot$ & $r$ & مدير مؤسسه حسابرسى & | س-الف \\
\hline r & • & - & - & r & سريرست مؤسسه حسابرسى & 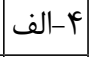 \\
\hline 1 & - & 1 & - & r & حسابدار رسمى غيرشاغل & |ه-الف \\
\hline r & - & - & - & r & دكترى حسابدارى و مديريت اجرايى & | \\
\hline 1 & r & • & - & f & دانشيار حسابدارى & |لف V \\
\hline 1 & $\cdot$ & - & - & 1 & |استاديار حسابدارى & |人-1الف \\
\hline 11 & q & V & 1 & ra & | مجموع & \\
\hline
\end{tabular}


همجنين، در يزوهش حاضر از ب ب مصاحبه ويدئويى نامزدهاى هفتمين دوره شوراى عالى إلى

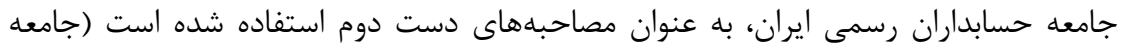

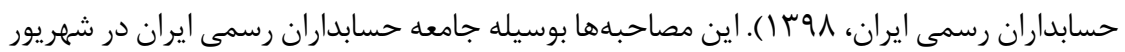

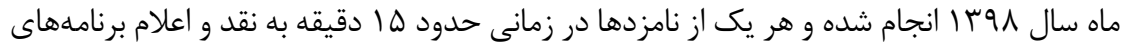

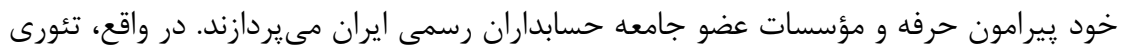

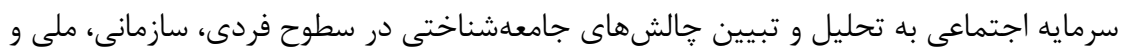

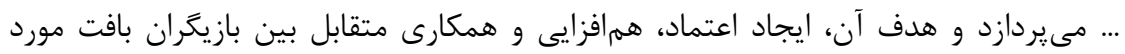

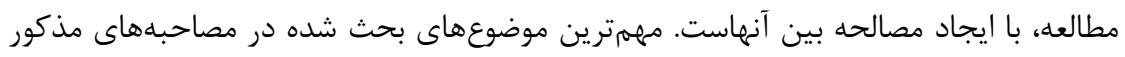

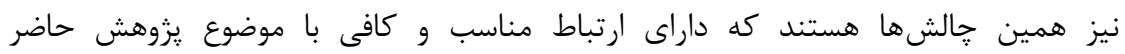

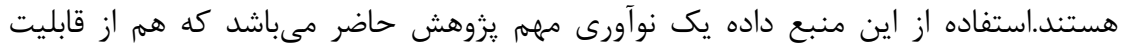

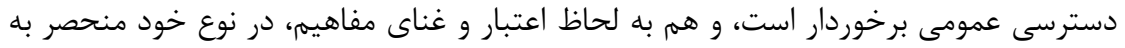
فرد است. از سوى ديخر، هدف از بررسى اين ويدئو ها، همانند مصاحبه هاى نئ نيمه ساختاريافته يزوهش، كشف مفاهيم، مقوله ها و ابعاد سرمايه اجتماعى مؤسسه حسابرسى است. در يزوهشهاى

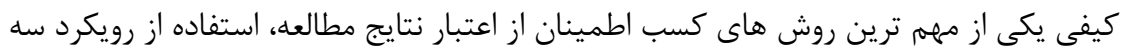

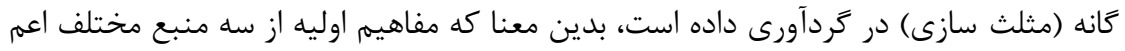

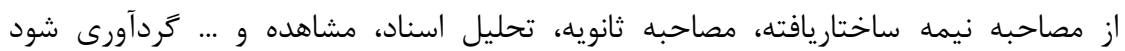

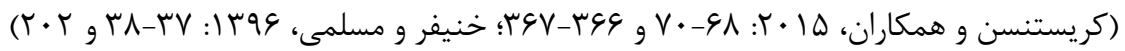

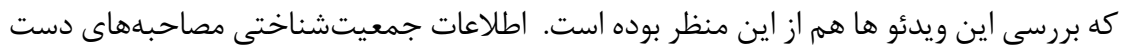
دوم به شرح جدول ب است.

جدول 9: اطلاعات جمعيتشناختى مصاحبههاى دست دوم

\begin{tabular}{|c|c|c|c|c|c|c|}
\hline سال 19 . 19. & 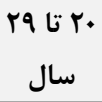 & 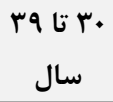 & بيشتر بال بال & جمع & سوابق حرفهاى / دانشعاهى & شناسه \\
\hline - & f & r & • & V & |عضو شوراى عالى جامعه حسابداران & ثا \\
\hline r & $\wedge$ & 1 . & r & זr & شريك مؤسسه حسابرسى & r \\
\hline - & . & 1 & . & 1 & معادل شريك مؤسسه حسابرسى & 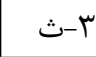 \\
\hline - & - & 1 & • & 1 & مدير مؤسسه حسابرسى & $\dot{H}$ \\
\hline - & 1 & - & - & 1 & حسابدار رسمى شاغل & ث \\
\hline 1 & r & r & - & $\Delta$ & حسابدار رسمى غيرشاغل & ث- \\
\hline r & 10 & iv & r & ґ^ & مجموع & \\
\hline
\end{tabular}


منبع سوم كردآورى داده در يزوهش حاضر، تحليل سه نشريه حرفهاى ايران شامل حسابدار

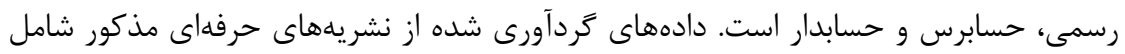

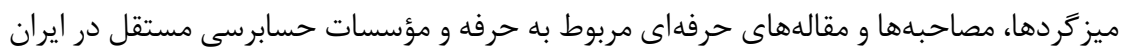

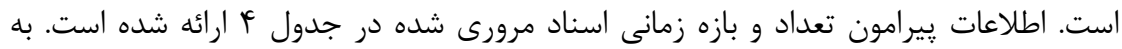

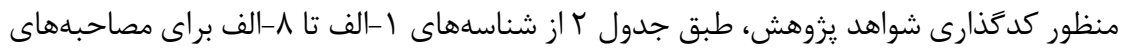

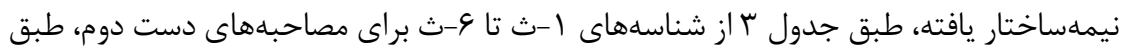

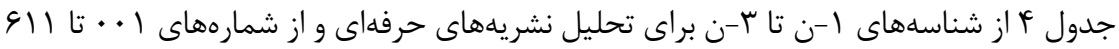
به عنوان شناسه واحد تحليل استفاده شده است.

جدول •ا: تعداد و بازه زمانى اسناد تحليل شده از نشريههاى حرفهاي

\begin{tabular}{|c|c|c|c|c|c|c|c|c|c|c|}
\hline $9 r$ & 94 & $q F$ & $9 \Delta$ & 99 & $9 V$ & $9 \wedge$ & 99 & تعداد مقاله & نشريه & شناسه \\
\hline . & Ir & $\Lambda$ & rt & rt & $V F$ & $v r$ & rI & TQT & حسابدار رسمى & 1 \\
\hline rv & ra & Tr & TV & Tr & $\cdot$ & rq & ra & 111 & حسابرس & r \\
\hline - & $\Delta$ & 48 & T\& & If & 11 & $\Delta$ & - & $1 \cdot V$ & حسابدار & ז-ץ \\
\hline rv & F & VV & $\wedge \Delta$ & $\varepsilon \wedge$ & $\Lambda \Delta$ & $1 \cdot V$ & is & $\Delta F \Lambda$ & مجموع & \\
\hline
\end{tabular}

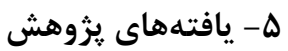

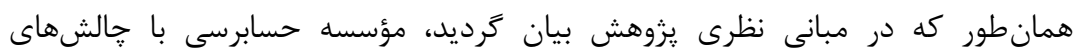

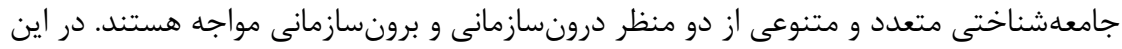

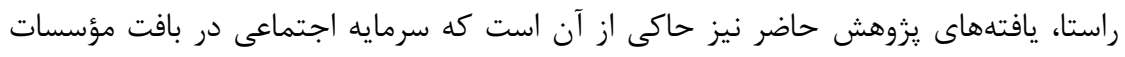

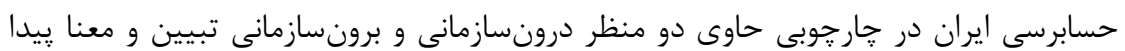

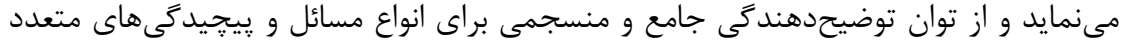

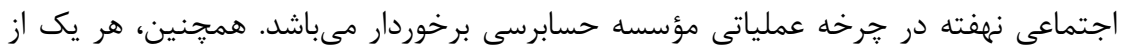

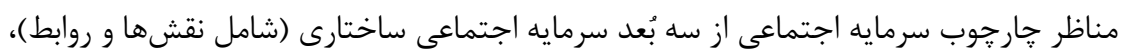
سرمايه اجتماعى شناختى (سياستها و ارزشهاى سازمانى)، و سرمايه اجتماعى رابطهاى (اعتماد،

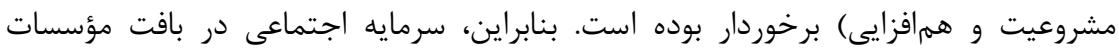

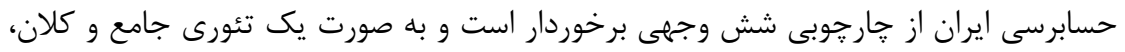

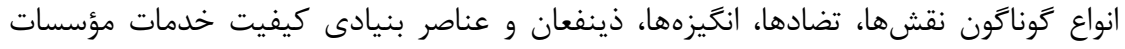

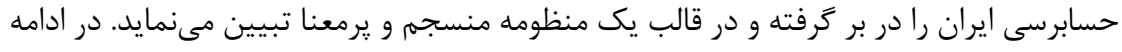


به اختصار هر يك از ابعاد سه كانه جارجوب و مفاهيم زمينهاى سازنده آنها از دو منظر درونسازمانى و برونسازمانى تشريح مى تردند.

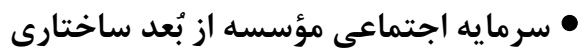

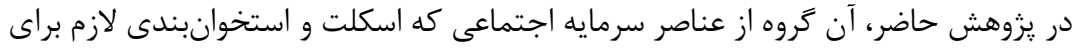

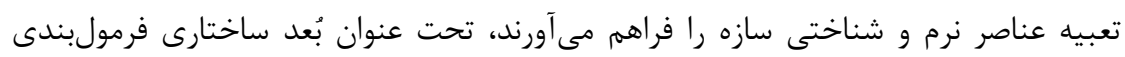

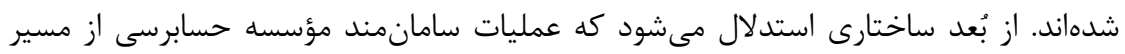

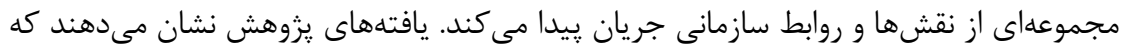

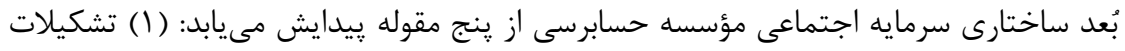

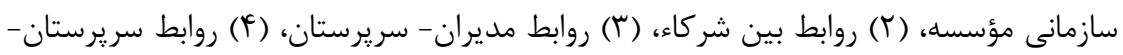
يرسنل، و (U) روابط اعضاء در فضاى مجازى. تشكيلات سازمانى به معناى مجموعهاى از وظايف و مناسبات تعبيه شده در سازمان مؤسسه

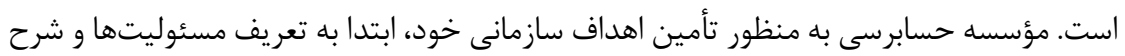

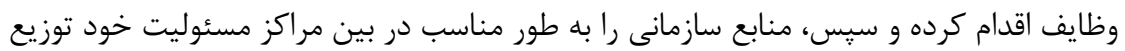
مىنمايد. عنصر كليدى در تكوين تشكيلات سازمانى مؤسسه، تركيب شركاء هستند. شركاء

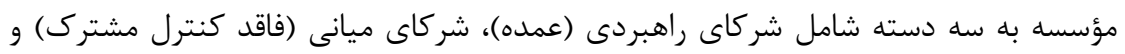

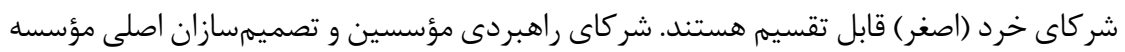
بوده، در عمليات بيشتر نقش نظارتى و غيرموظف را ايفا مىنمايند، و از بيشترين منافع مالكانه

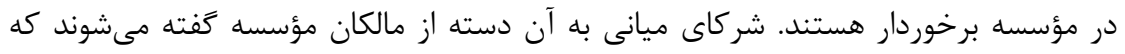

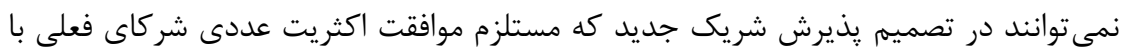

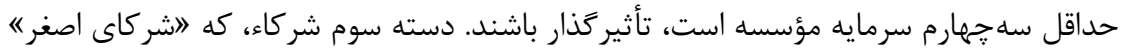

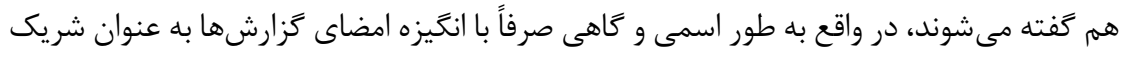

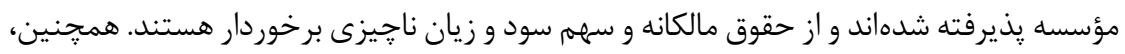

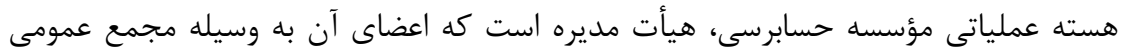

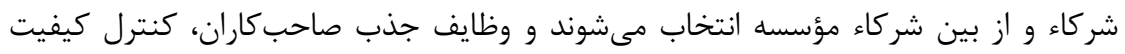

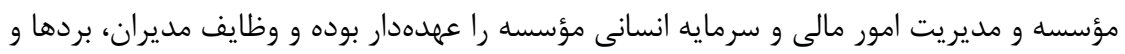

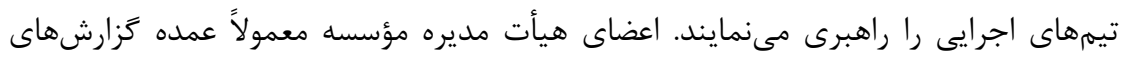

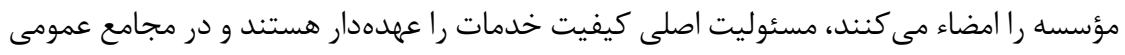
صاحبكاران حضور مىيابند.

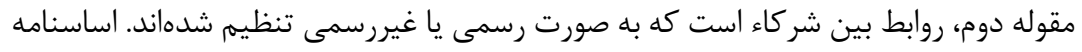

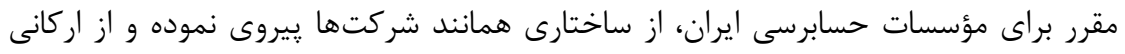


شامل مجمع عمومى شركاء، هيأت مديره و حسابرس تشكيل شده است. با اين وجود، نظام

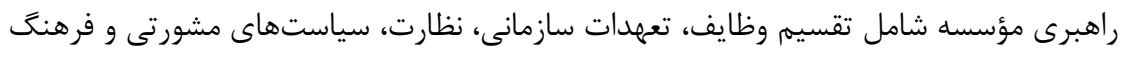

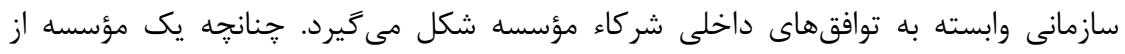

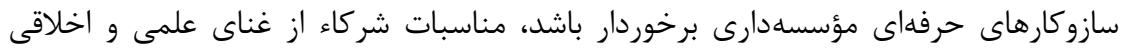
بالاترى برخوردار مىشوند.

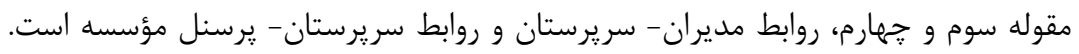

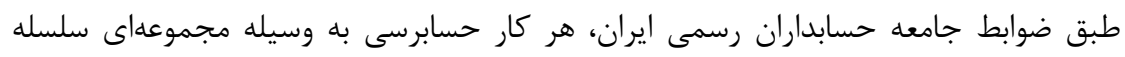

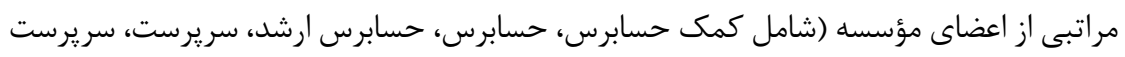

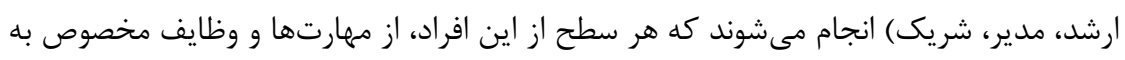

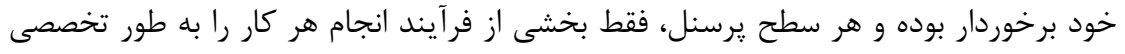

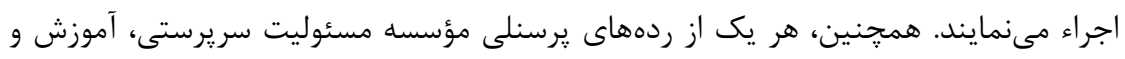

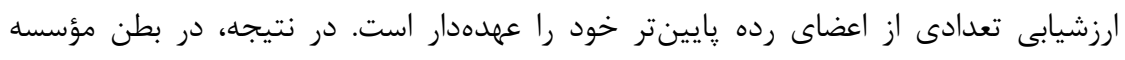

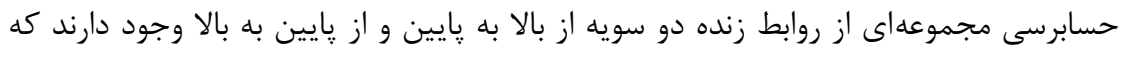

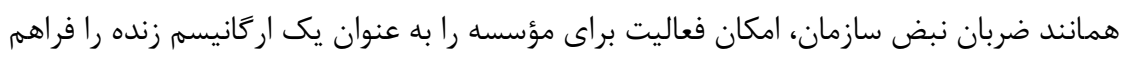
مى آورند. در نهايت، ينجمين مقوله منظر درونسازمانى سرمايه اجتماعى ساختارى، روابط اعضاء

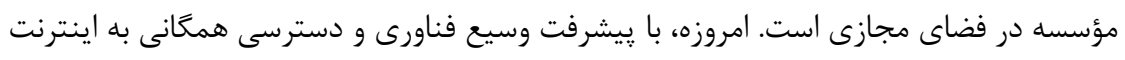

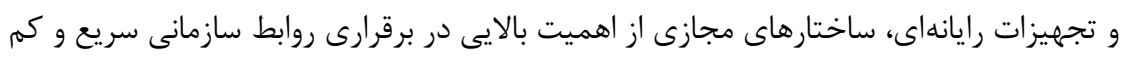

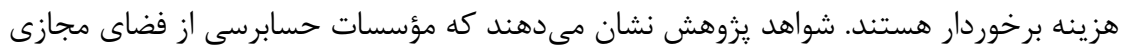

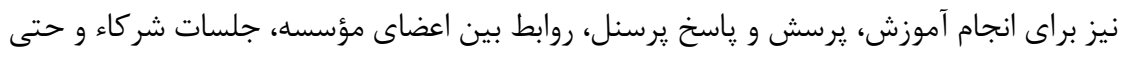

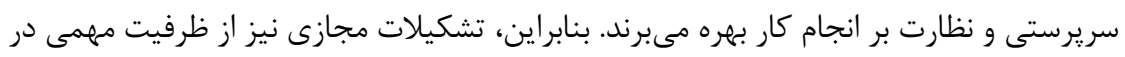

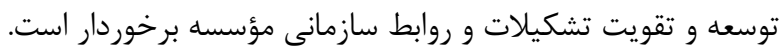

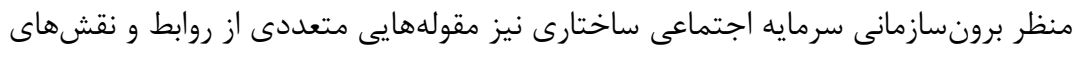

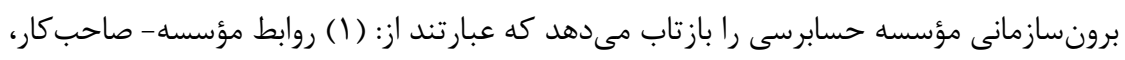

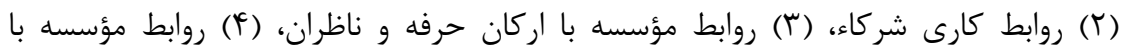

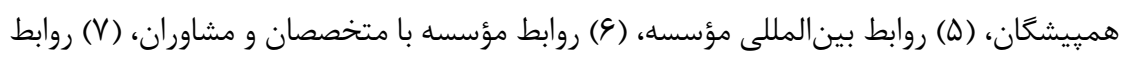

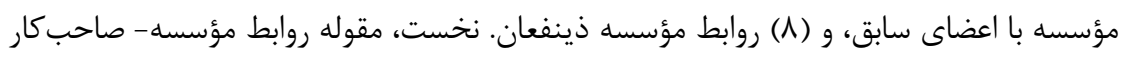

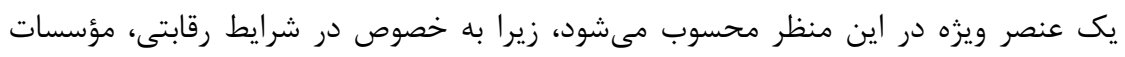

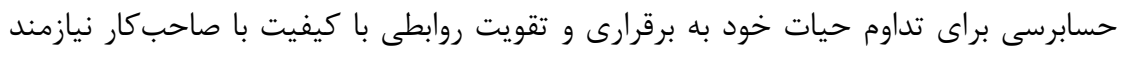

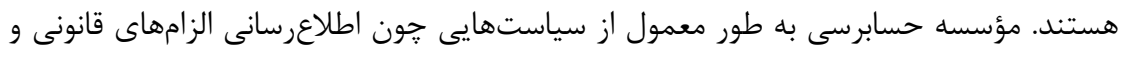


مقر راتى، جلسات آموزشى، تعامل و هممفكرى نسبت به مسائل فىمابين استفاده مىنمايند. علاوه

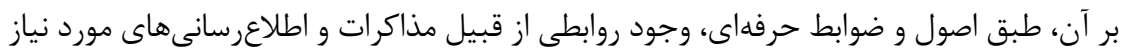

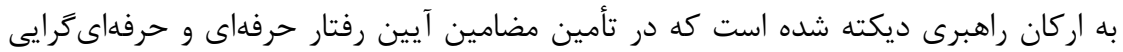
حسابداران رسمى نقشى كليدى دارند.

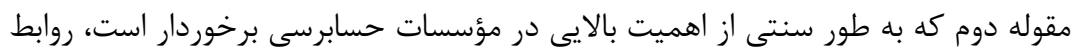

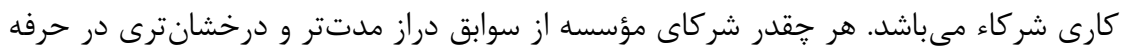
برخوردار باشند، به طور طبيعى با بازيخران مختلفى از محيط سياسى، اقتصادى و اجتماعى كشور

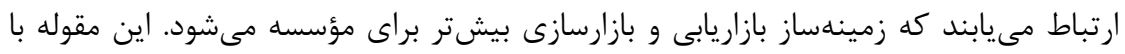

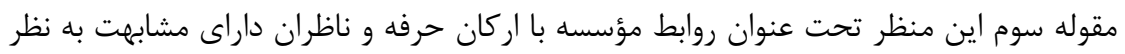

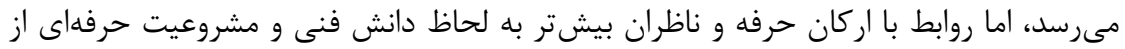

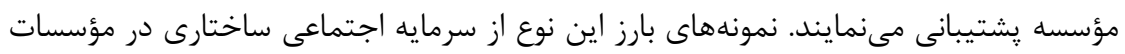

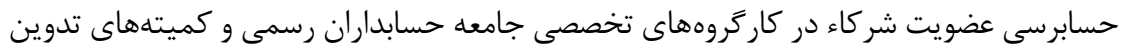
استاندارد سازمان حسابرسى است. مقوله جهارم، روابط مؤسسه با همييشكان خود است. در قوانين و مقررات جامعه حسابداران

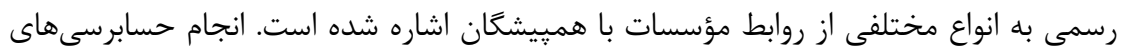

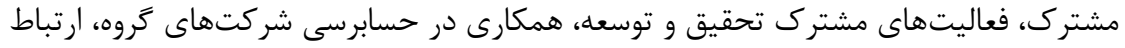
با حسابرس جانشين و حتى حسابرسى خود مؤسسات حسابرسى و خودانتظامى هميريشعان

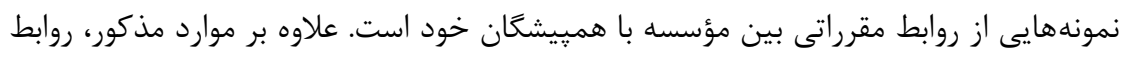

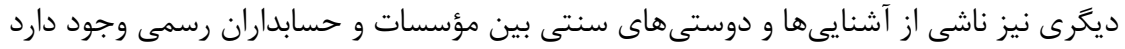

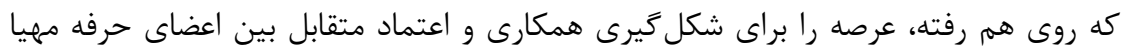

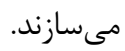

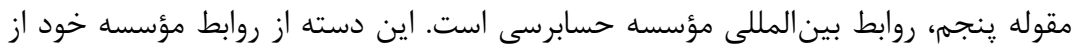

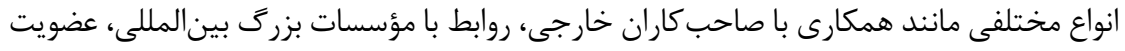

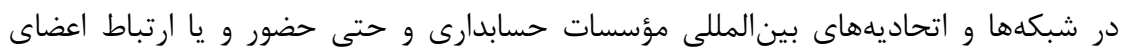

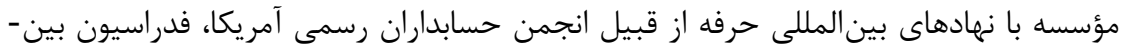
المللى حسابداران و انجمن حسابداران خبره رسمى برخوردار مى بـاشد. در همين راسئ راستا، مقوله

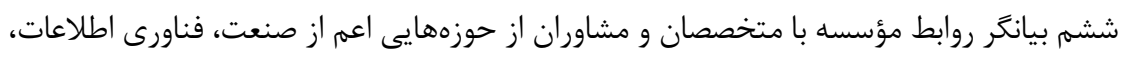

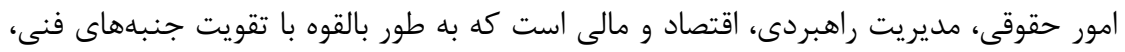

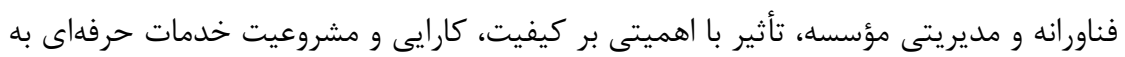
ارمغان مى آورند. 
مقوله هفتم اين منظر، به روابط مؤسسه با اعضاى سابق خود اشاره دارد. منظور از اعضاى

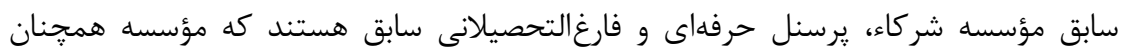

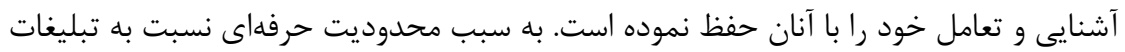

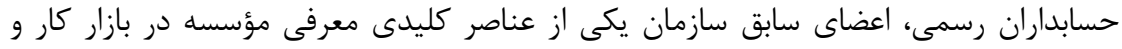

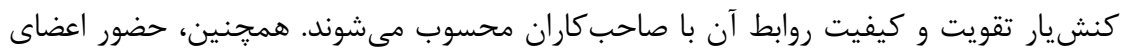

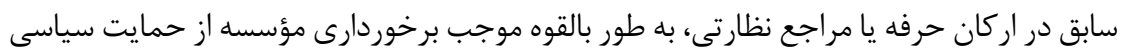

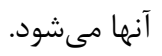

در نهايت، مقوله هشتم منظر برونسازمانى سرمايه اجتماعى ساختارى مؤسسه، روابط

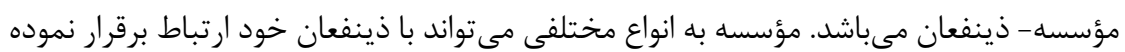

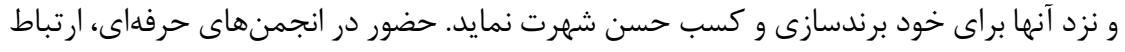

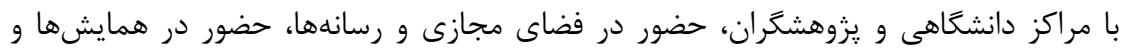

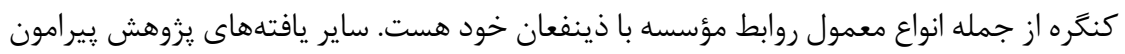
بُعد سرمايه اجتماعى ساختارى مؤسسه حسابرسى در جدول ها ارائه شده است.

جدول ||: جار جوب سر مايه اجتماعى مؤسسات حسابر سى ايران - بُعد ساختارى

\begin{tabular}{|c|c|}
\hline \multicolumn{2}{|l|}{ منظر درونسازمانى } \\
\hline 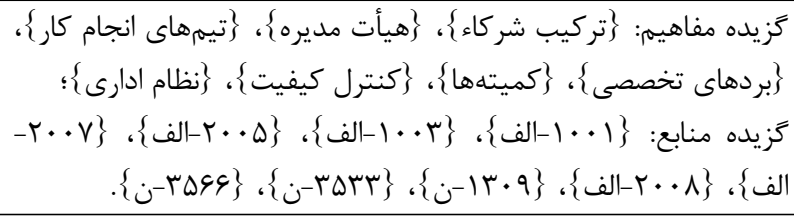 & مأسسه؛ \\
\hline 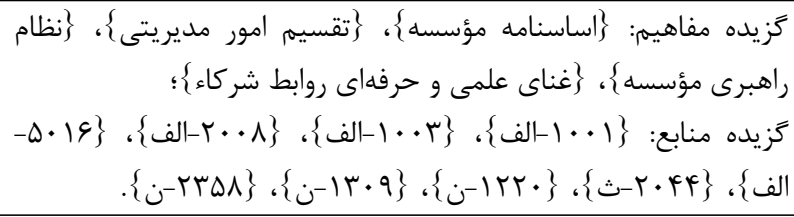 & ז. روابط بين شر كاء؛ \\
\hline 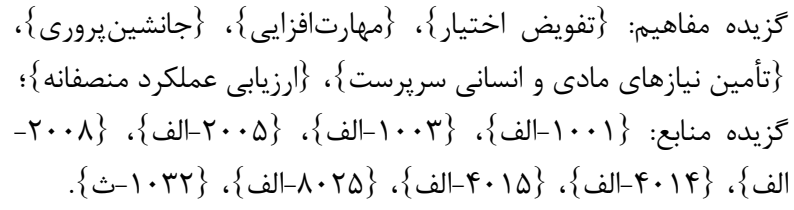 & سريرستان؛ روابط \\
\hline 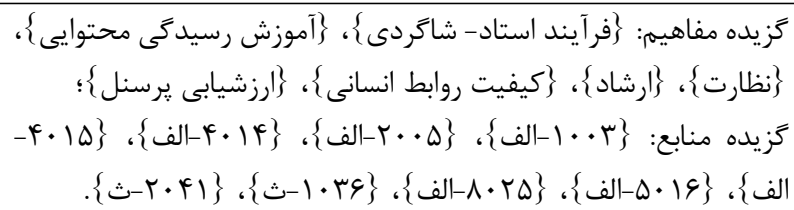 & 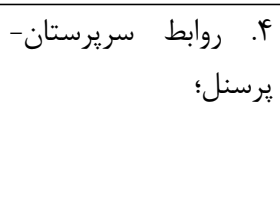 \\
\hline
\end{tabular}


دو فصلنامه حسابدارى ارزشى و رفتارى، سال ينجم، شماره دهم، پِاييز و زمستان وجسا

\begin{tabular}{|c|c|}
\hline 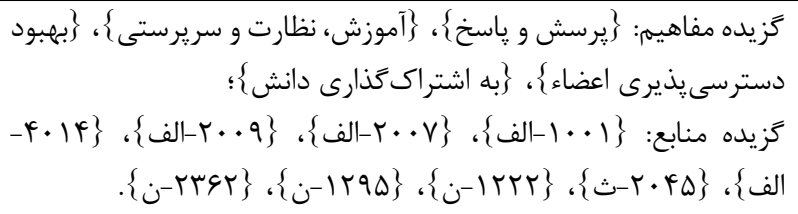 & هـ مجازى. روابط اعضاء در فضاى \\
\hline \multicolumn{2}{|l|}{ منظر برونسازمانى } \\
\hline 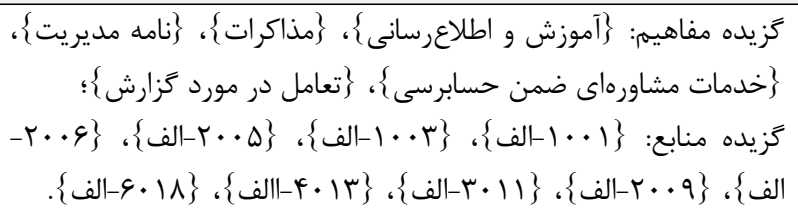 & صاحبكار؛ \\
\hline 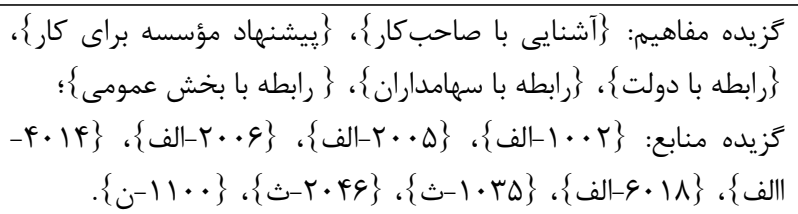 & ז. روابط كارى شركاء؛ \\
\hline 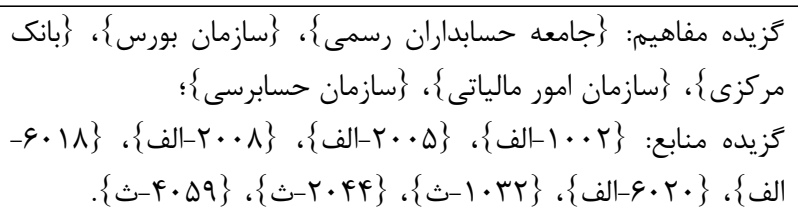 & $\begin{array}{r}\text { r. روابط مؤسسه با اركان } \\
\text { حرفه ناظران؛ }\end{array}$ \\
\hline 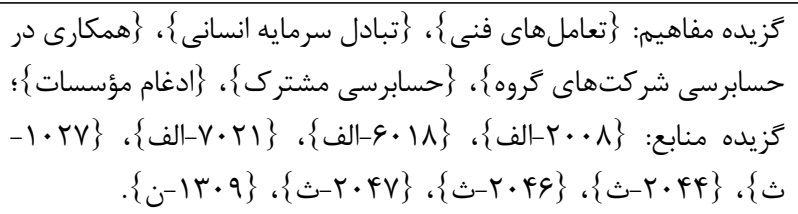 & 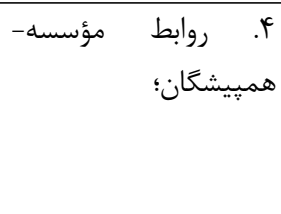 \\
\hline 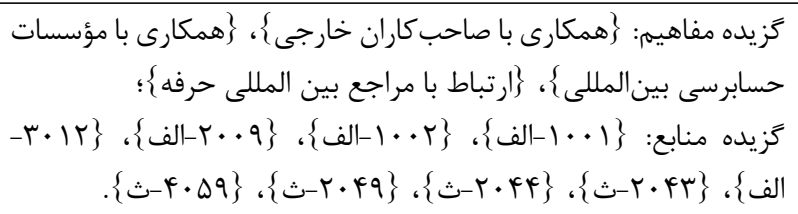 & 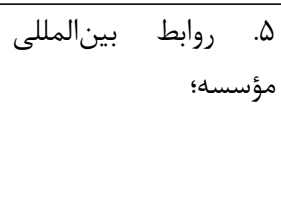 \\
\hline 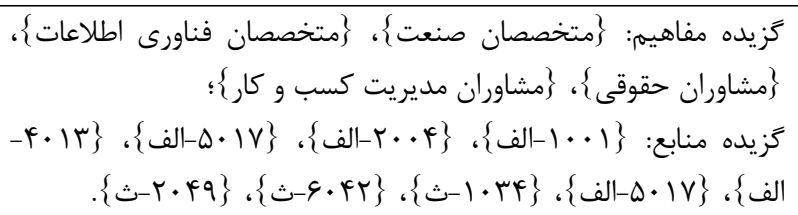 & و. متخصصان و مشاوران؛ مؤسسه با بان \\
\hline 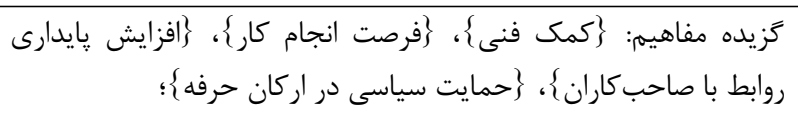 & 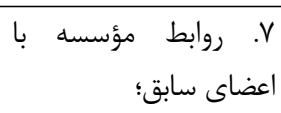 \\
\hline
\end{tabular}


دكتر مهربانيور و همكاران، جارجوب سرمايه اجتماعى براى مؤسسات حسابرسى ايران

\begin{tabular}{|c|c|}
\hline 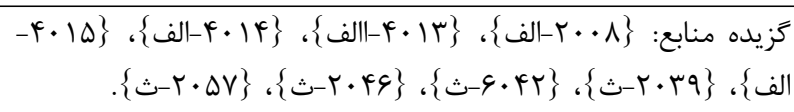 & \\
\hline 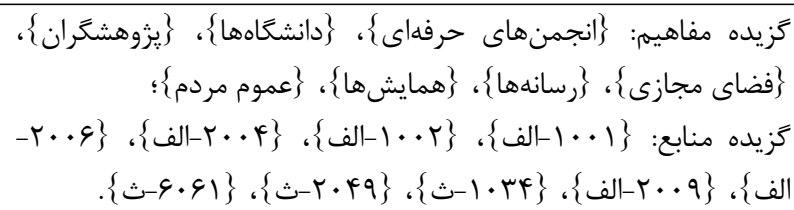 & ذينفعان. روابط مؤسسه- \\
\hline
\end{tabular}

• سر مايه اجتماعى مؤسسه از بُعد شناختى

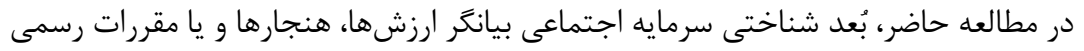

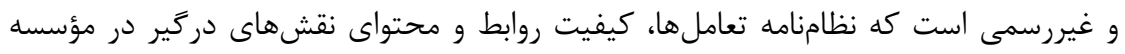
حسابرسى را تعيين و تبيين مىنمايند. از منظر درونسازمانى، اين بُعد از سرمايه اجتماعى مؤسسه

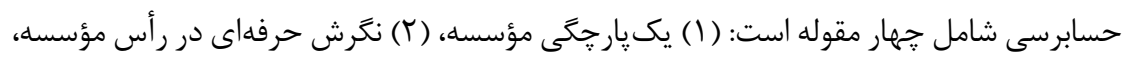

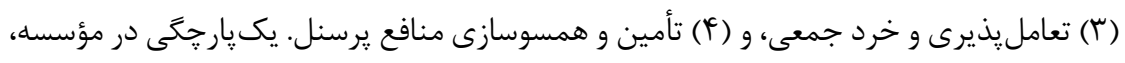

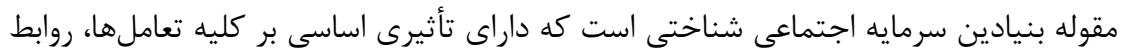

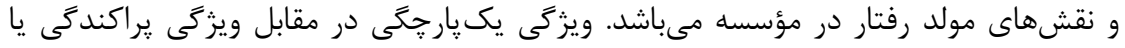

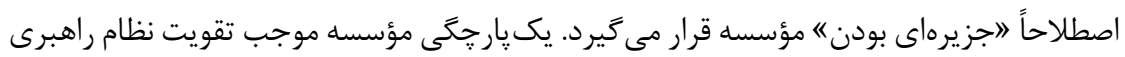

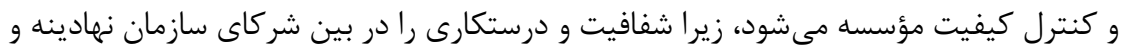

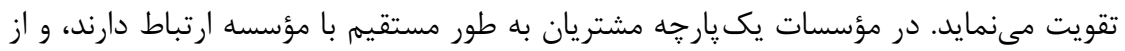

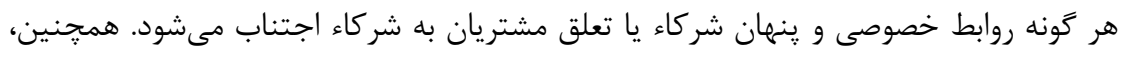

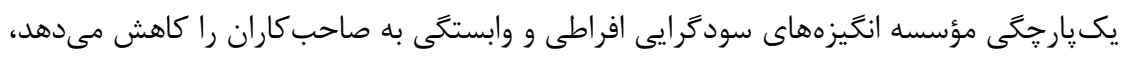

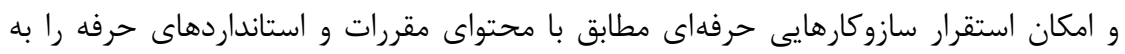

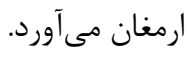
مقوله شناختى دوم، نكَرش در رأس مؤسسه است. نخرش در رأس مؤسسه به سياستهاى

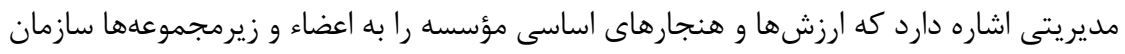

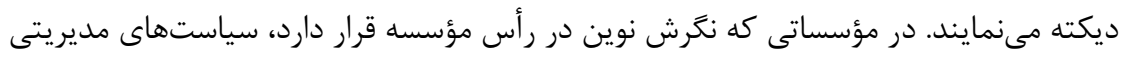

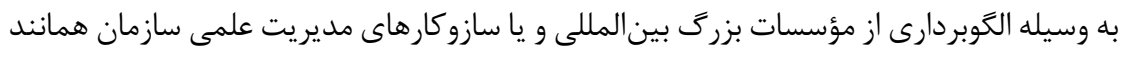

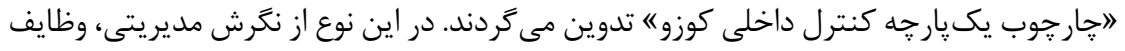

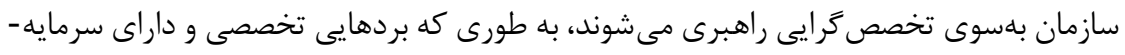

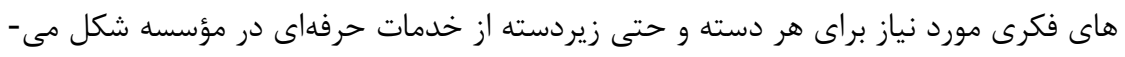

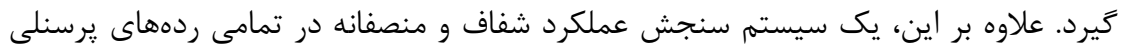


مؤسسه و به صورت سلسله مراتبى تعريف مىشود و سياستهاى تشويقى و تنبيهى به صورت

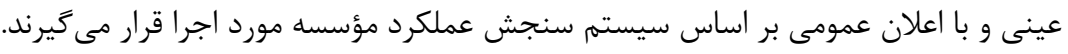

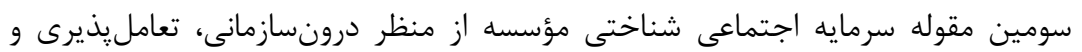
خردجمعى است. در تيم انجام كار، تبادلنظر و استفاده از عقل جمعى نهتنها يكى از از الزامهاى

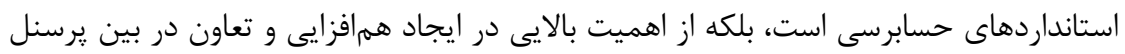

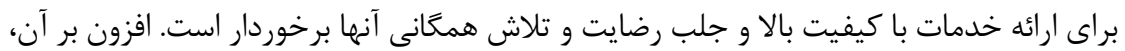
مؤسسه حسابرسى مى تواند از سياستهاى مختلفى مثل سيستم انتقادها و ييشنهادها و جلسات

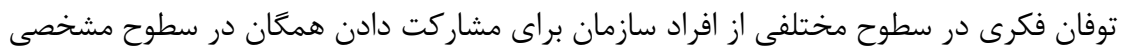

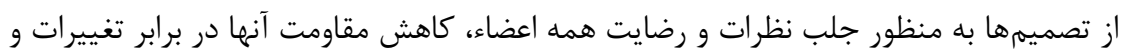
ايجاد اتحاد و تعاون همكانى در برآورده نمودن اهداف سازماني إنى استفاده نمايد.

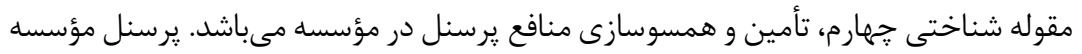

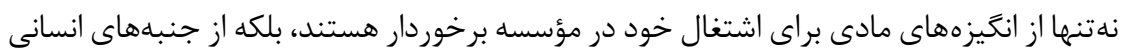
و شخصيتى نيز داراى خواستهايى بوده كه انتظار دارند مؤسسه به تأمين آنها متعهد و وايبند

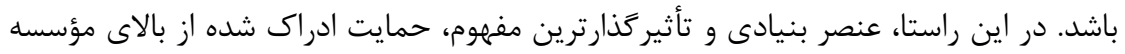

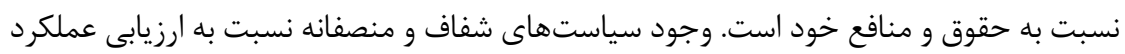

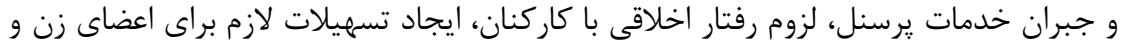

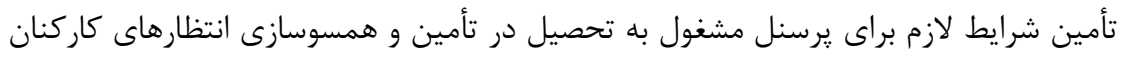

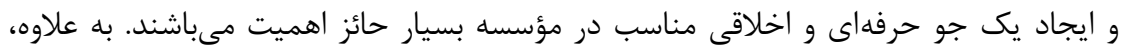

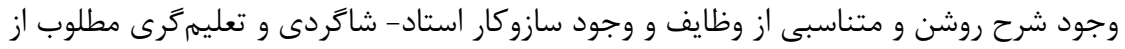

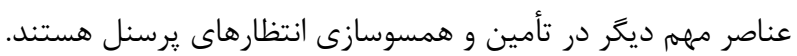

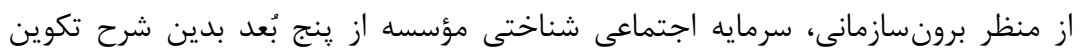

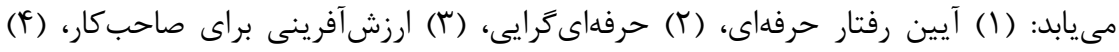

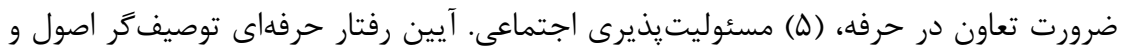

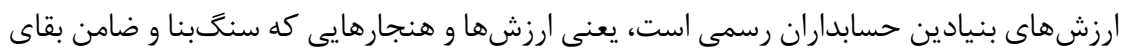

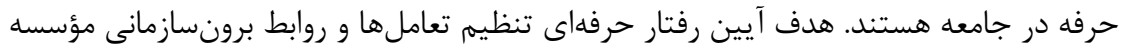

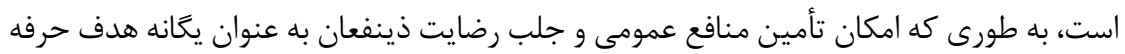

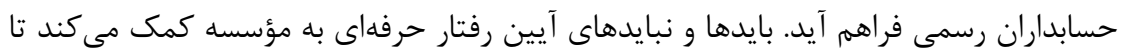

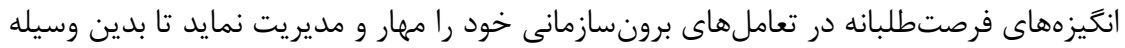

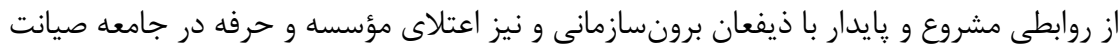


مقوله شناختى دوم، حرفهاى گرايى مؤسسه در روابط برونسازمانى خود است. حرفهاى گرايى

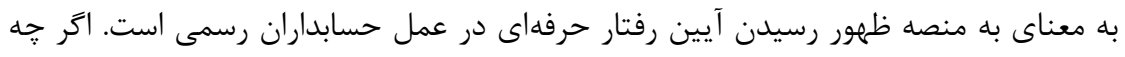

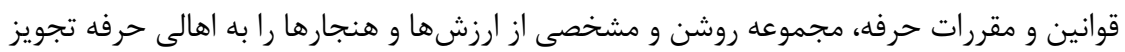

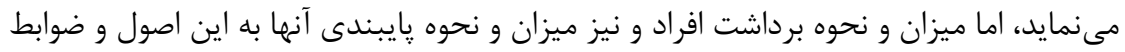

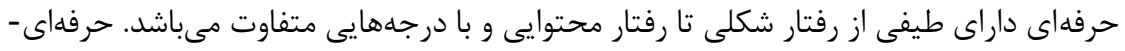

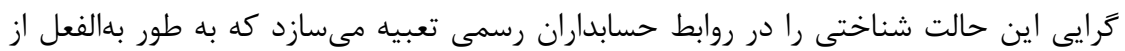
مرجعيت علمى، تخصصى و تجربى لازم در خدمات حرفهاى خود برخوردار باشد، كيفيت خدان آندات

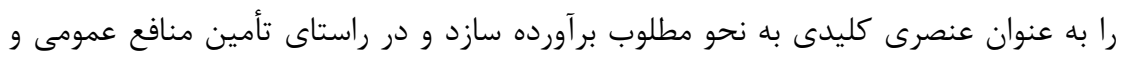

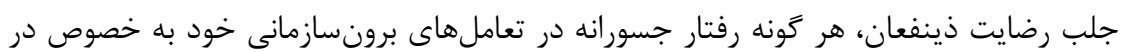

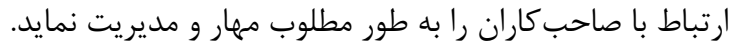

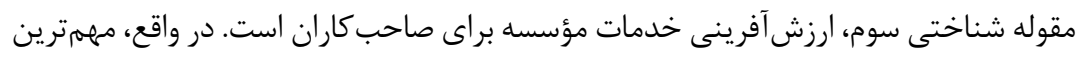

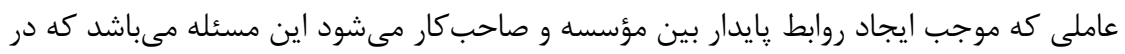

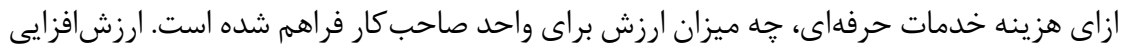

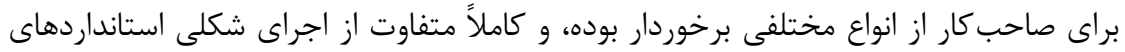

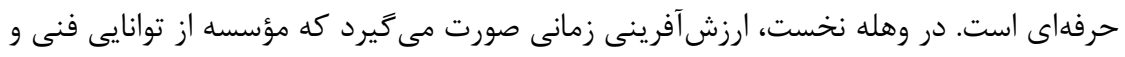

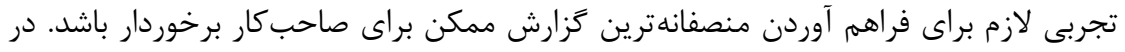

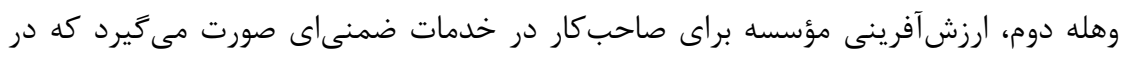

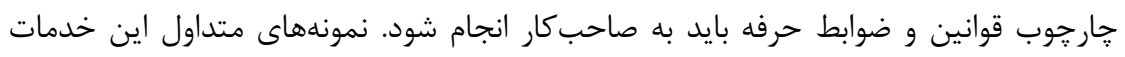

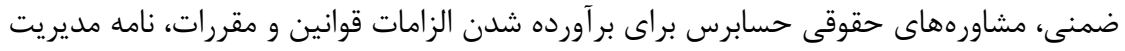

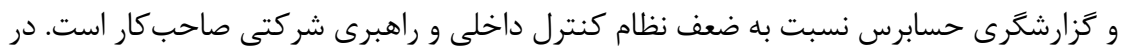

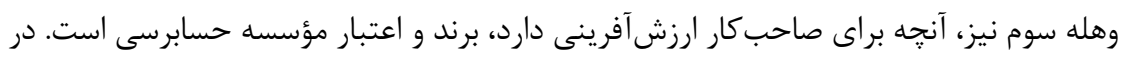

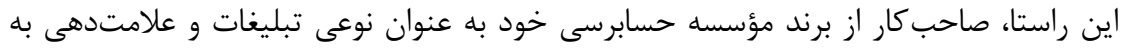

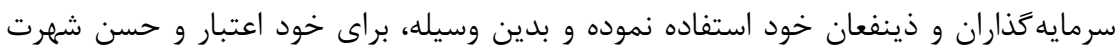
مىسازد.

مقوله شناختى جهارم، ضرورت تعاون در حرفه است. تعاون بين مؤسسات حسابرسى از دو

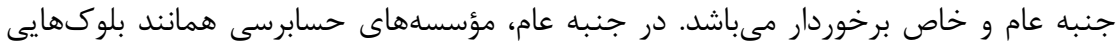

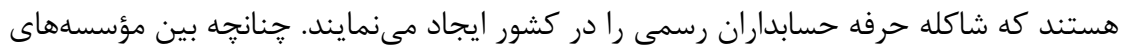

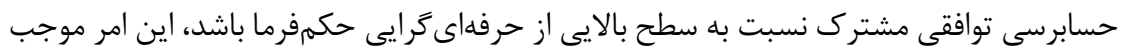
ايجاد اتحاد و هم|فزايى در اجراى اصول و ضوابط حرفهاى در سطح كلان شده و اعتلاء و توسعه

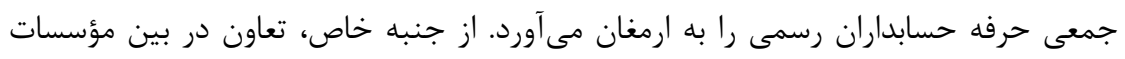


حسابرسى مى تواند به صورت همكارى مشترك دو يا جند مؤسسه در ارائه خدمات حرفهاى،

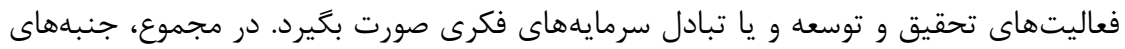

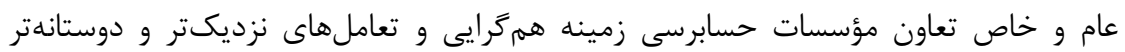

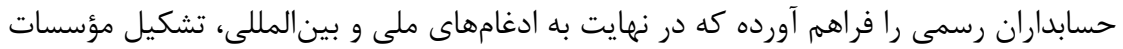

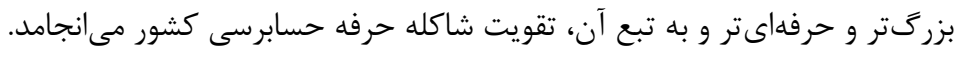

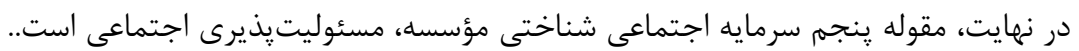

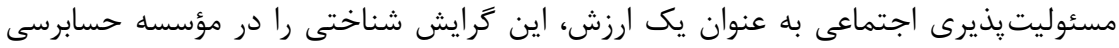

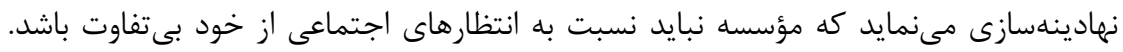

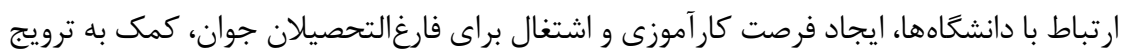
آموزش و يزوهش در حرفه، معرفى حرفه در سطح كشور، كمكهاى انساندوستانه، مشاركت در در دران

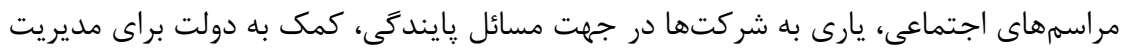

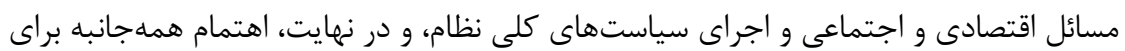
كمك به جامعه در دستيابى به توسعهاى بايدار در زمينههاى رفاه اقتصادى و اجتماعى از مهمهترين

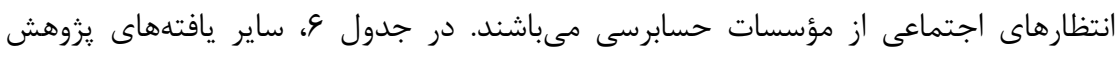

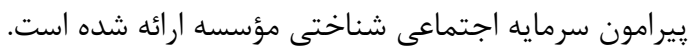

جدول זا: جارجوب سرمايه اجتماعى مؤسسات حسابر سى ايران - بُعد شناختى

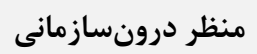

\begin{tabular}{|c|c|}
\hline 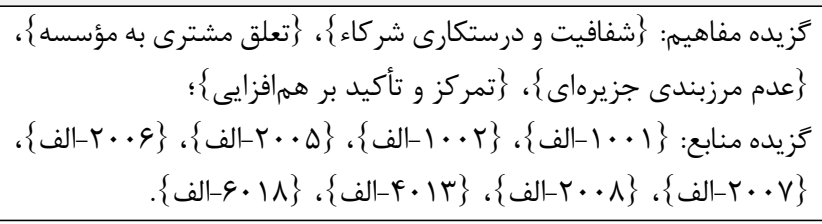 & '. \\
\hline 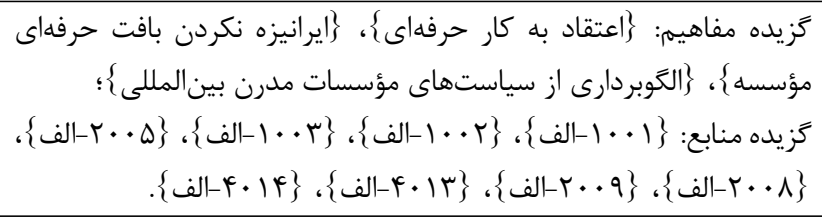 & رأ. نكَرش مؤسسه؛ حرفهاى در \\
\hline 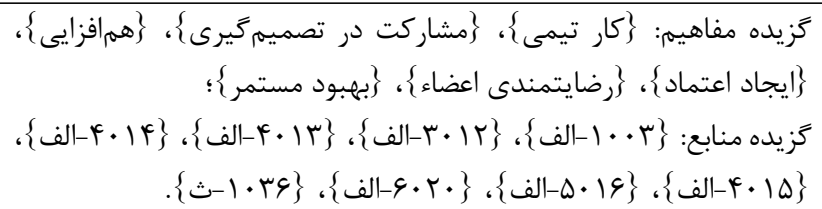 & حم. تعامل؛ \\
\hline
\end{tabular}




\begin{tabular}{|c|c|}
\hline 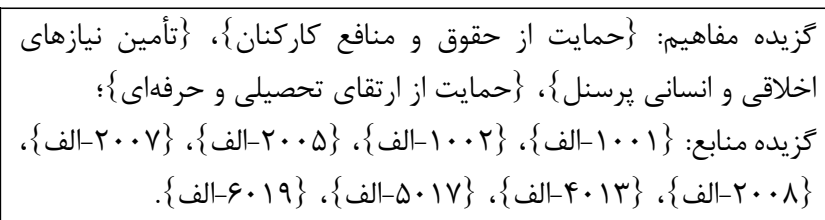 & 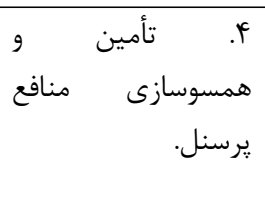 \\
\hline \multicolumn{2}{|l|}{ منظر برونسازمانى } \\
\hline 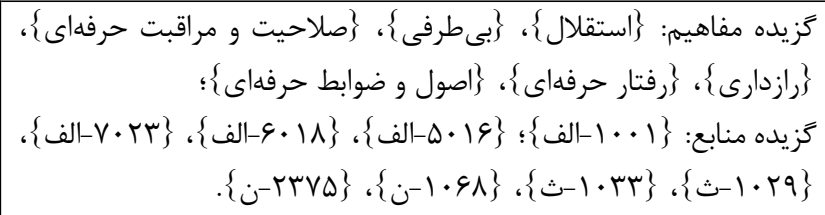 & ا. آيينرفتار حرفهاى؛ \\
\hline 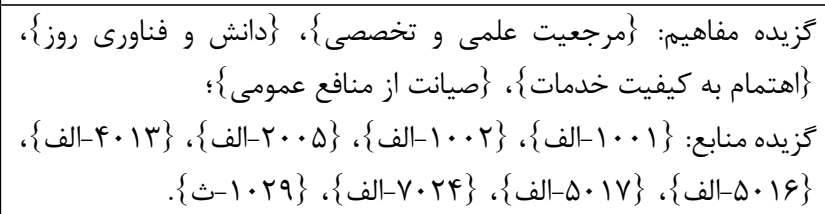 & عَرايى؛ \\
\hline 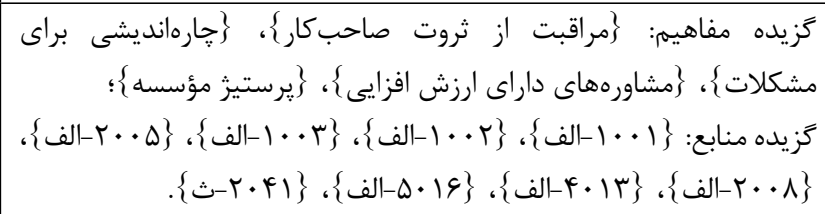 & صاحب ارزشار؛ \\
\hline 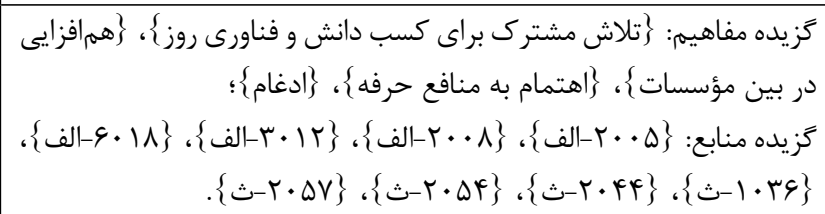 & 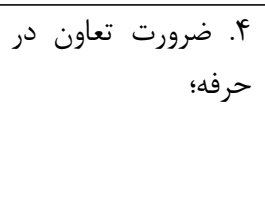 \\
\hline 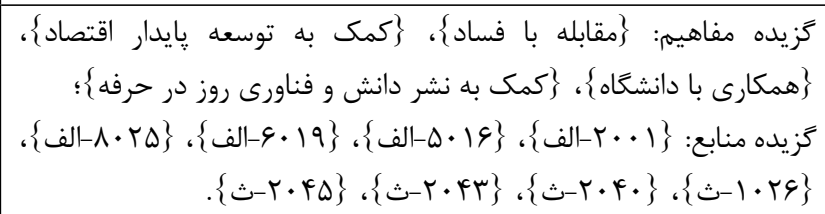 & ه. هـ مسئوليتيذيرى \\
\hline
\end{tabular}

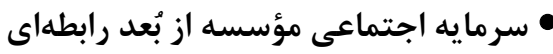

در يروهش حاضر، سرمايه اجتماعى رابطهاى به معناى منافع مشهود و نامشهودى است كه كه به واسطه دو بُعد ديخر (يعنى سرمايه اجتماعى ساختارى و شناختى)، به طور بالقوه عايد مؤسسه حسابرسى مىشود. از منظر درون سازمانى، سرمايه اجتماعى رابطهاى به وسيله مجموعهاى

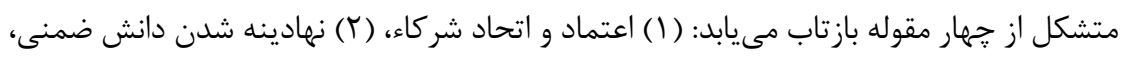
(r) اعتماد و اتكايذيرى يرسنل، و (Y) همافزايى درونى و رشد طبيعى مؤسسه. در اين راستا، 
اعتماد و اتحاد شر كاء مههمترين مقوله است، زيرا داراى تأثيرى بنيادين بر ساير مقولههاى سرمايه

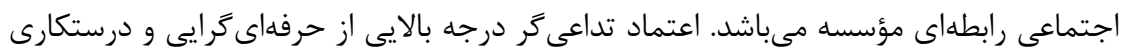

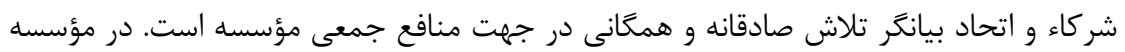

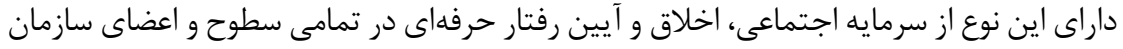

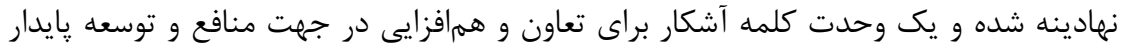
مؤسسه وجود دارد.

مقوله رابطهاى دوم، نهادينهسازى دانش ضمنى در مؤسسه است. مهمترين سرمايه يك

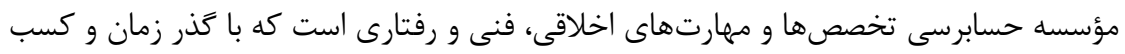

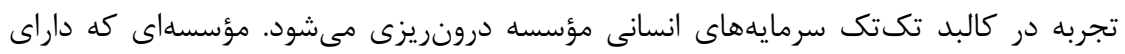

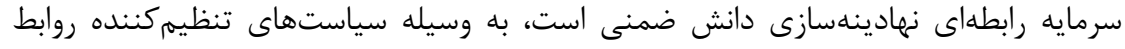

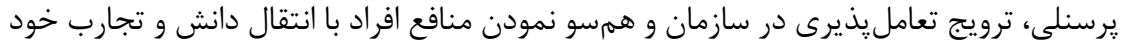

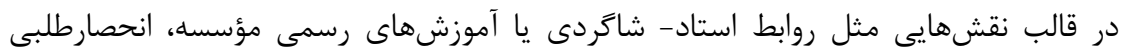

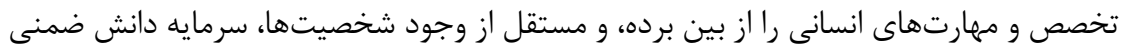

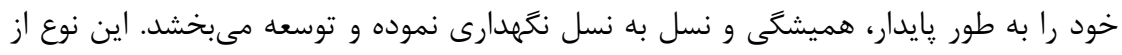

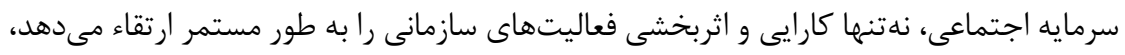

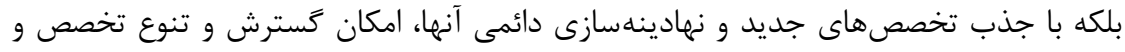
خدمات را نيز براى سازمان تسهيل مى تخدمايد.

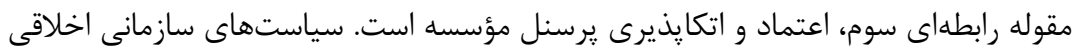
و حرفهاى، نهتنها موجب يرورش يافتن يرسنلى قابل اعتماد و اتكايذير براى مؤسسه مى إنود، بلكه

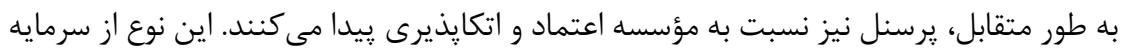

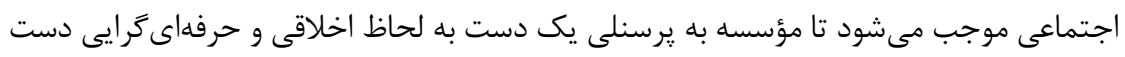

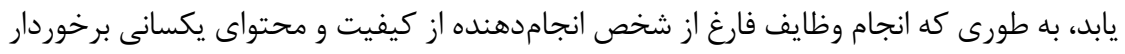

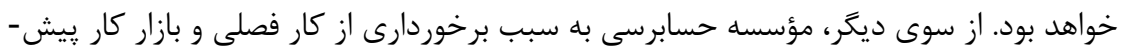

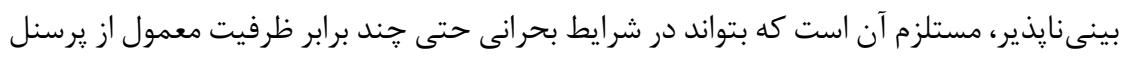

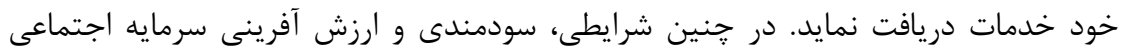

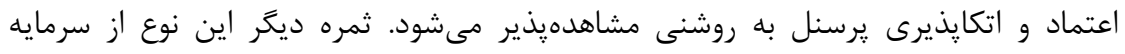

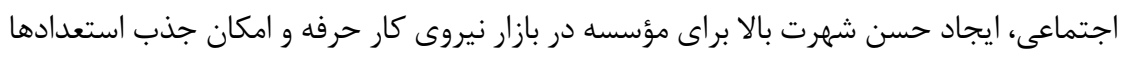
و تخصص هاى برتر در مؤسسه است.

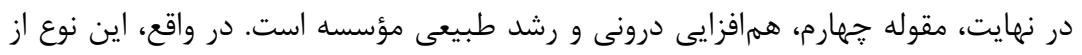

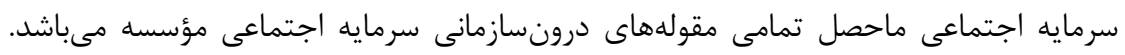


توسعه و توجه به روابط درون سازمانى و تنظيم سياستهاى اخلاقى و حرفهاى به منظور تأمين

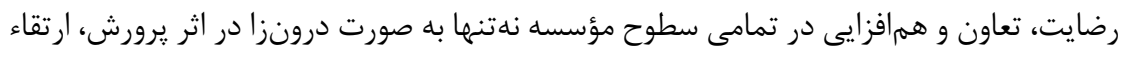

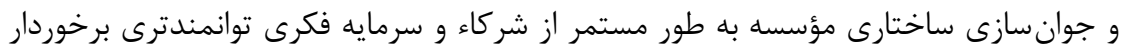

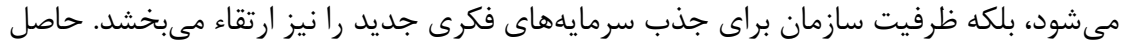

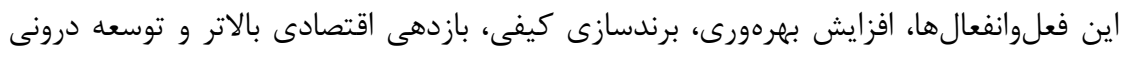
يايدار براى مؤسسه است.

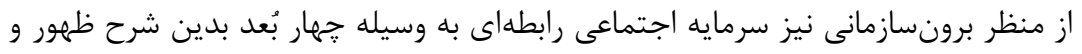

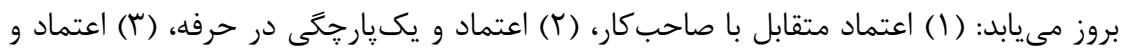

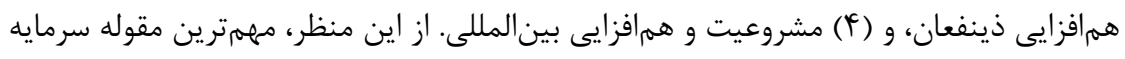

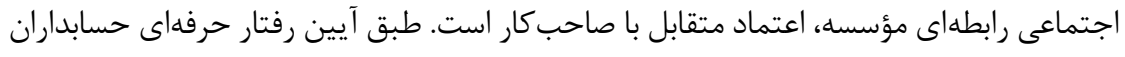

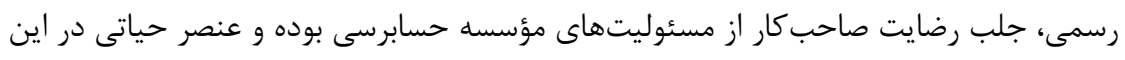

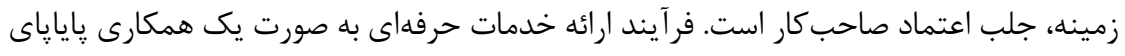

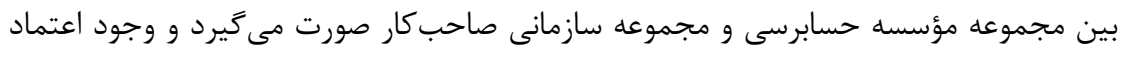

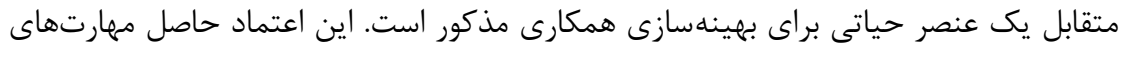

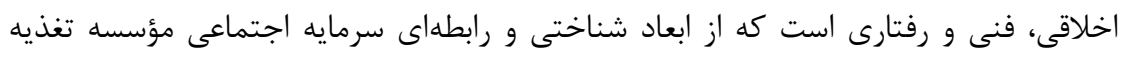

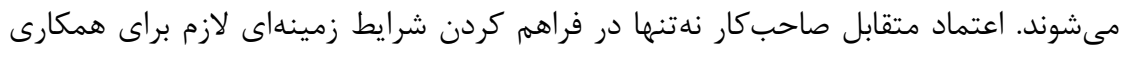

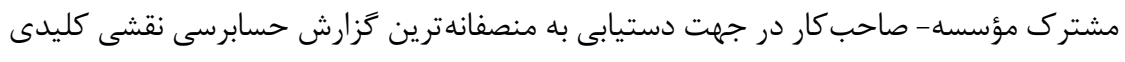

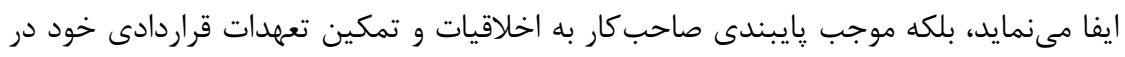

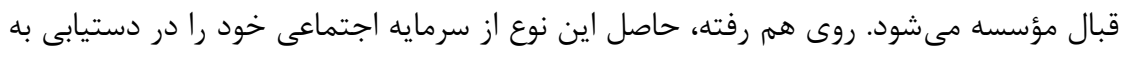

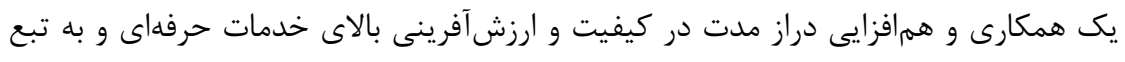

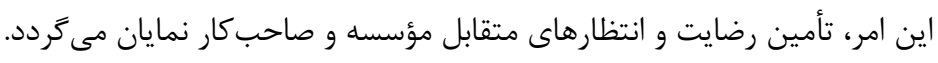

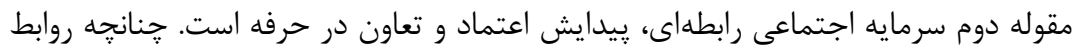

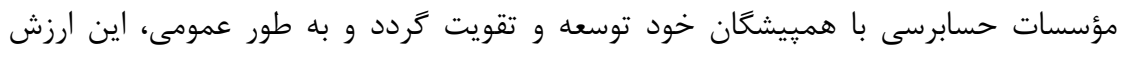

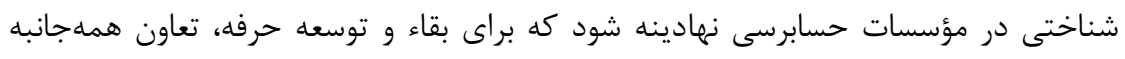

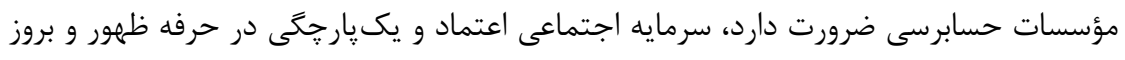

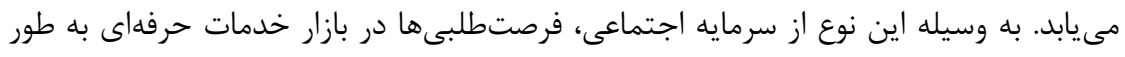

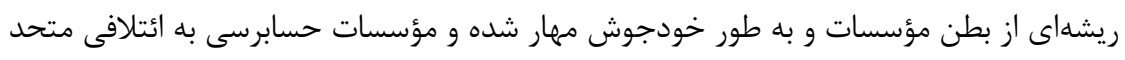

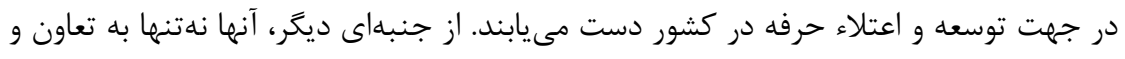

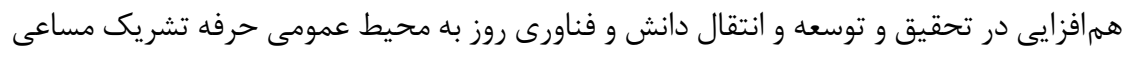

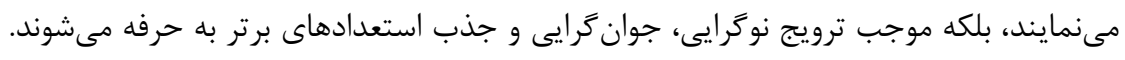


افزون بر آن، به وسيله اين نوع از سرمايه اجتماعى، به سبب ايجاد وحدت رويه و همدلى در

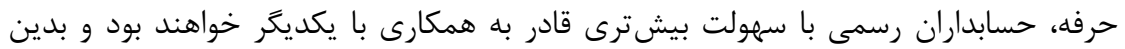

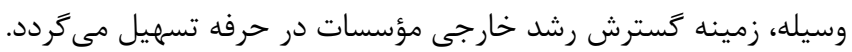

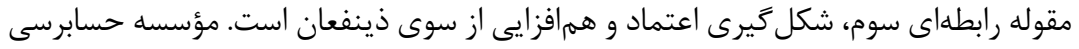

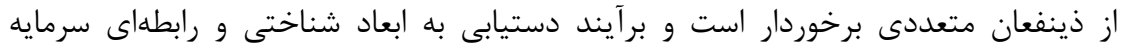

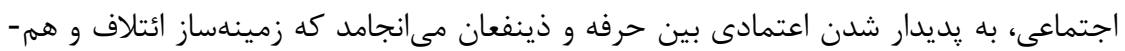

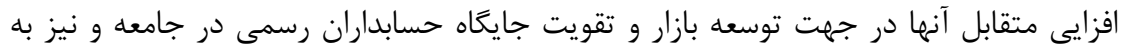

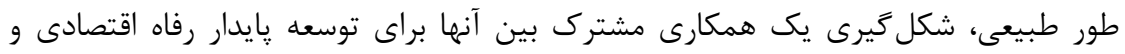

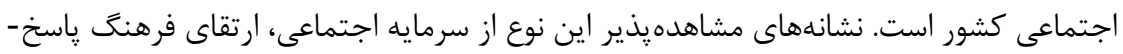
خواهى و ياسخ گويى در جامعه، افزايش تقاضاى داوطلبانه براى خدمات حرفهاى مؤسسات

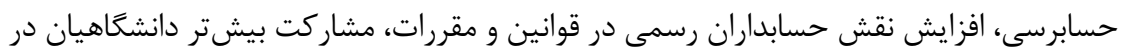

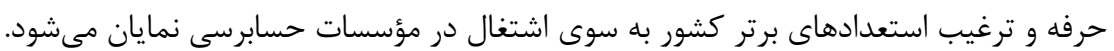
سرانجام، جهارمين مقوله رابطهاى، مشروعيت و همافزايى بين المللى است. ابعاد شناختى و و

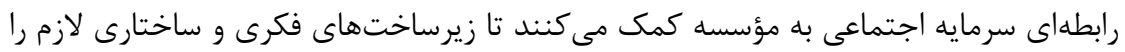

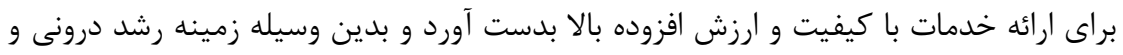
خارجى سازمان فراهم گردد. يكى از فرصتهاى رشد و هممافزايى ديكر كه در اين مسير عايد

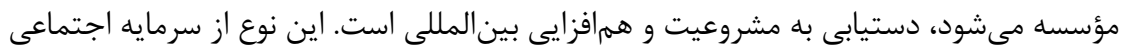

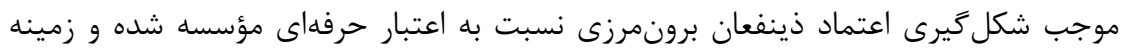

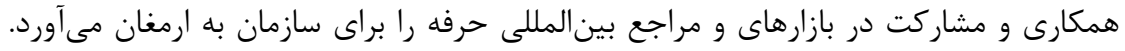

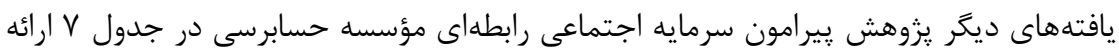

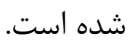

جدول با: جارجوب سرمايه اجتماعى مؤسسات حسابر سى ايران - بُعد رابطهاى

\begin{tabular}{|c|c|}
\hline \multicolumn{2}{|l|}{ منظر درونسازمانى } \\
\hline 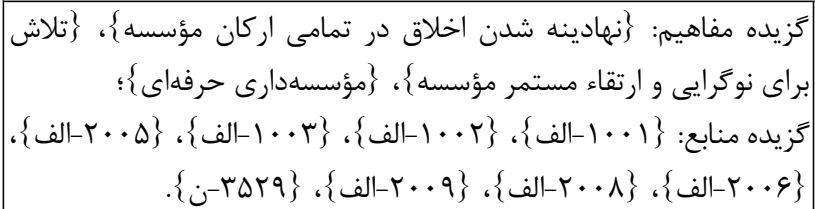 & 1. اعتماد و اتحاد شر كاء؛ \\
\hline 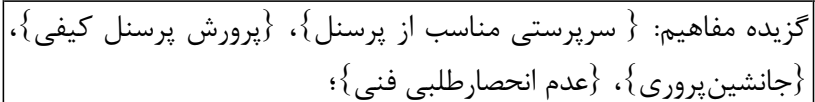 & ضمنى؛ \\
\hline
\end{tabular}




\begin{tabular}{|c|c|}
\hline 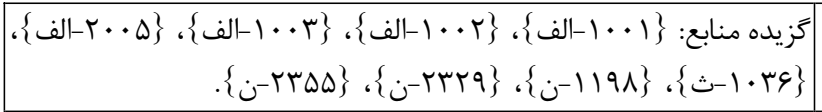 & \\
\hline 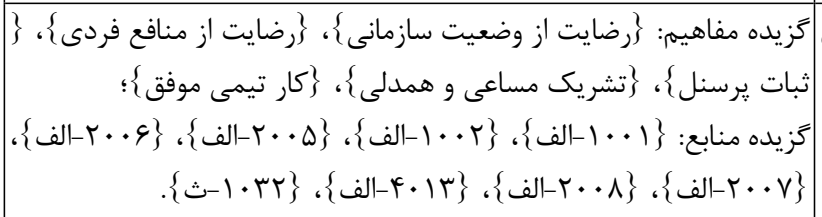 & 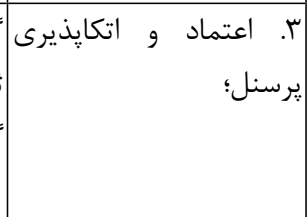 \\
\hline 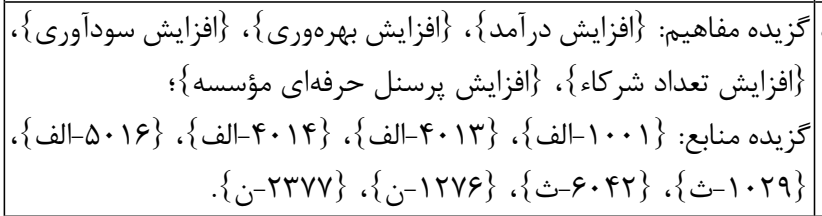 & طبيعs \\
\hline منظر برونسازمانى & \\
\hline 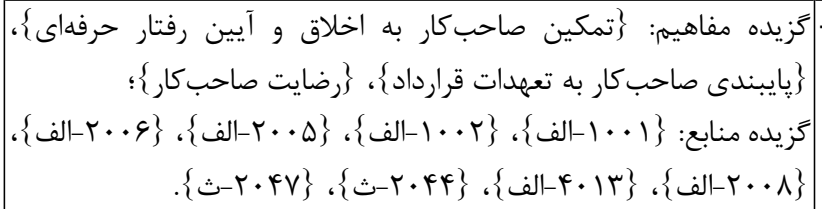 & \\
\hline 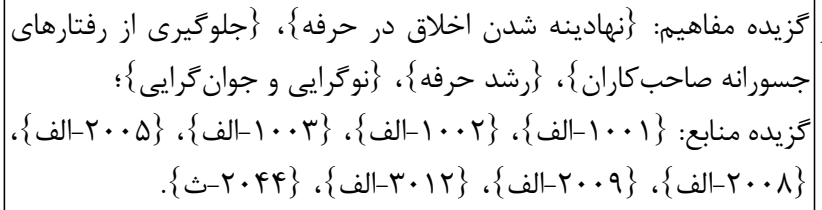 & 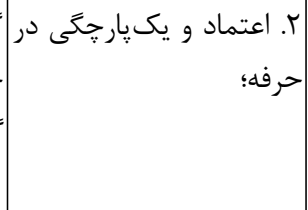 \\
\hline 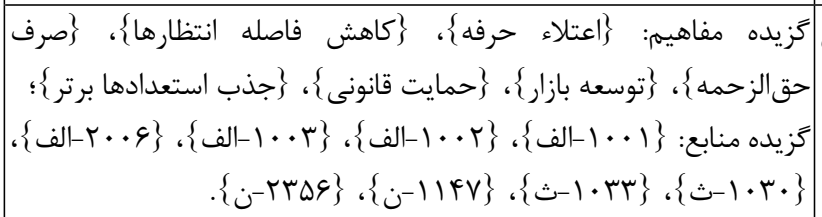 & ذينفعان؛ \\
\hline 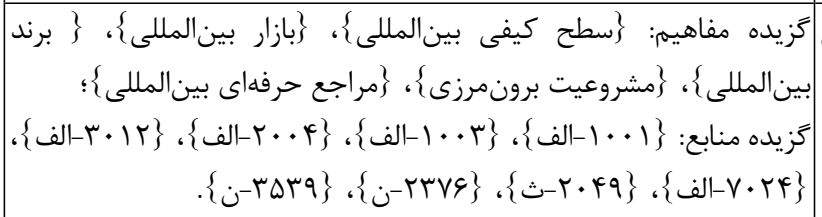 & 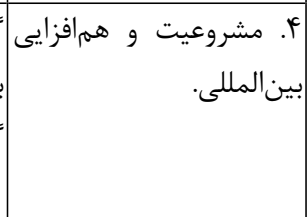 \\
\hline
\end{tabular}

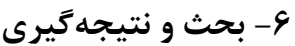

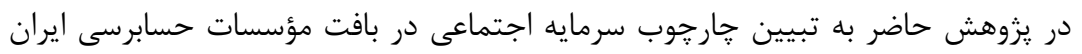

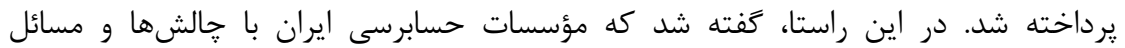

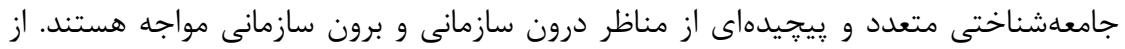


منظر درون سازمانى، مسائلى از قبيل تضاد منافع شركاء و يرسنل، جزيرهاى بودن، عدم رشد و

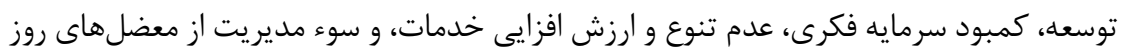

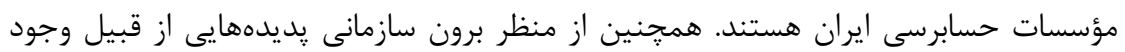
رقابت حاد، امضاء فروشى، رخداد رسوايىهاى مالى، شيوع بىاخلاقىهاى حرفهاى، حقالز الزحمه

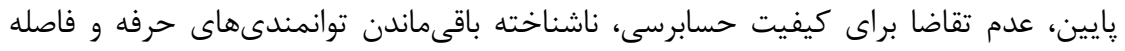

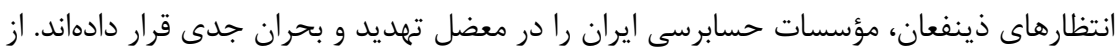

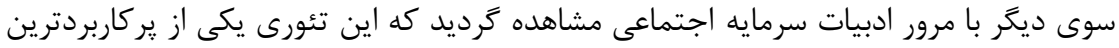

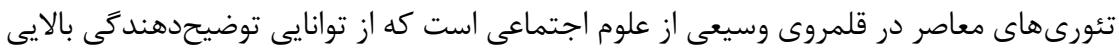

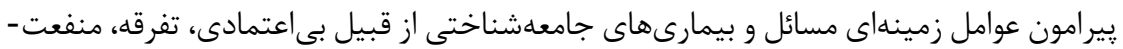

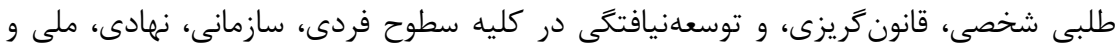
بين الملى برخوردار است.

در اين راستا، جارجوب يزوهش حاضر سرمايه اجتماعى مؤسسه حسابرسى را به صورت سازهاى شش وجهى از دو منظر درون سازمانى و برون سازمانى و سه بُعد ساختارى، شناختى و

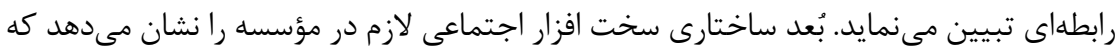

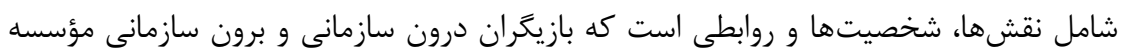

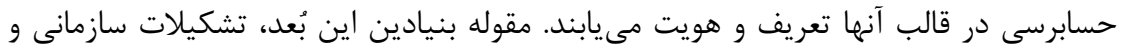

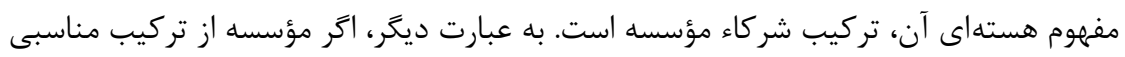

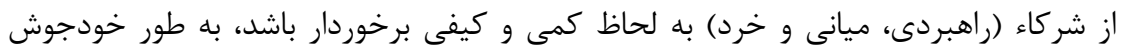
مؤسسه از تشكيلات سازمانى مدون برخوردار مى شود، غناى علمى و حرفهاى شركاء

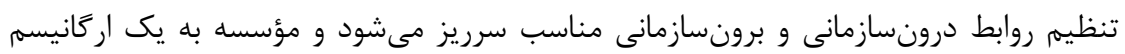

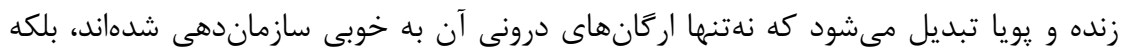

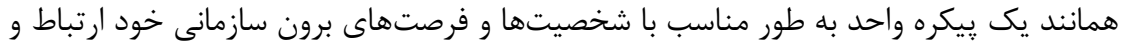

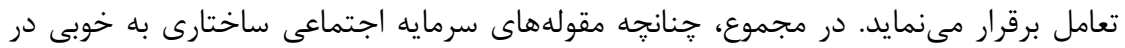

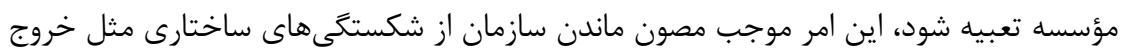

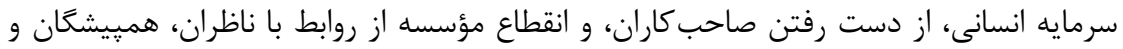
طرفهاى بينالمللى مىشود.

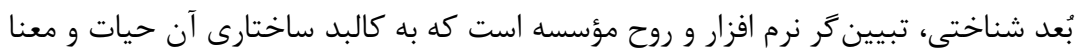

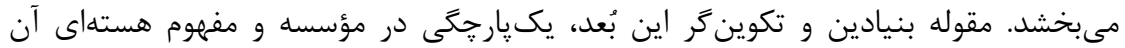

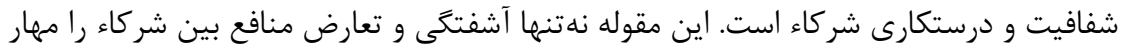

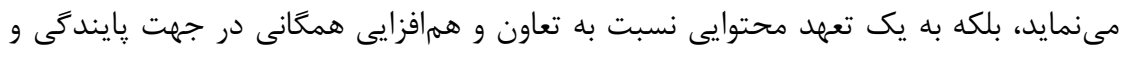


اعتلاى مؤسسه حسابرسى مى انجامد. بر اين مبنا، مؤسسه نغرشى در رأس خود بر يايه اعتقاد به إنها

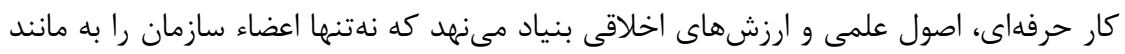

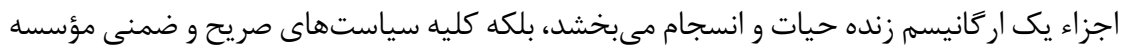

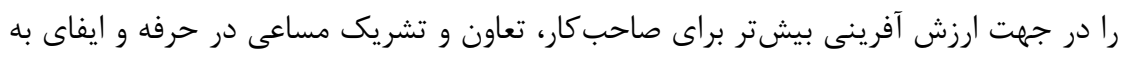

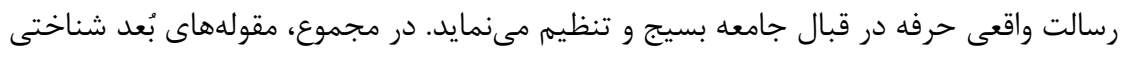

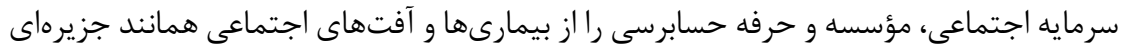

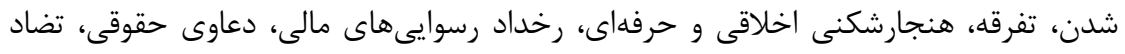

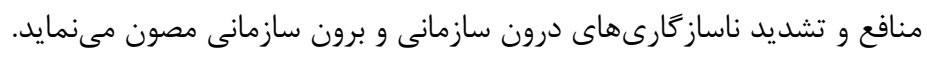

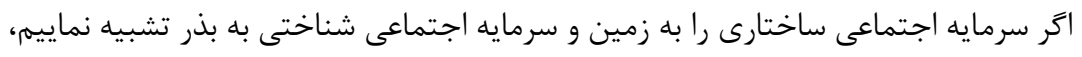

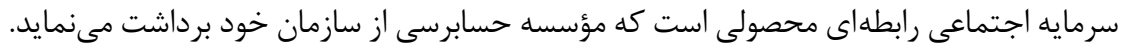

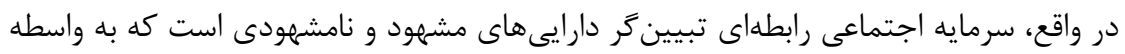

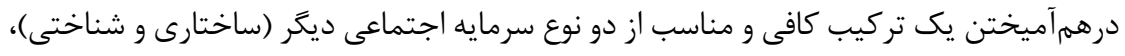

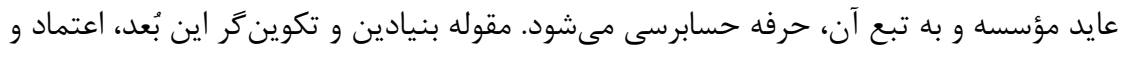

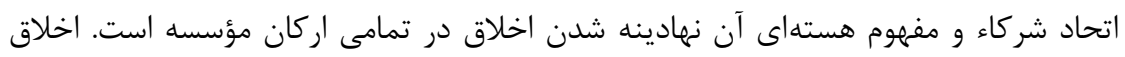

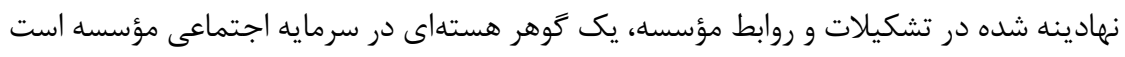

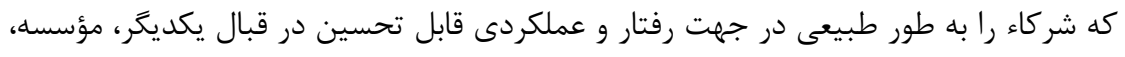

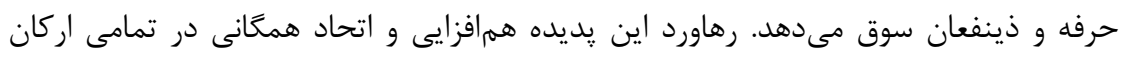

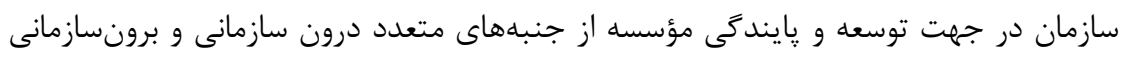

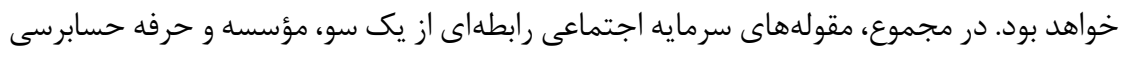

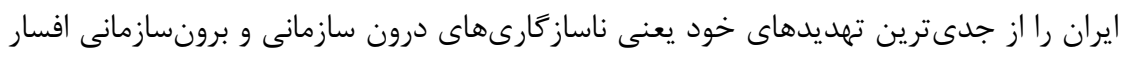

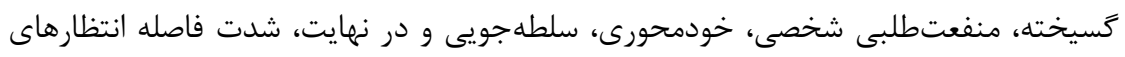

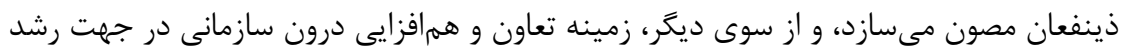

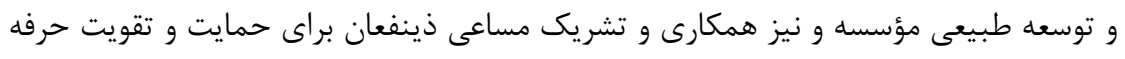

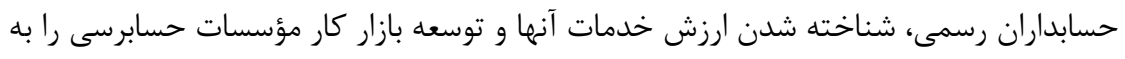
ارمغان مى آورد. در مجموع، حار جوب حاصل از تبيين سرمايه اجتماعى در بافت مؤسسه حسابرسى يكى سازه

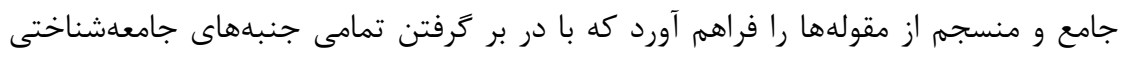

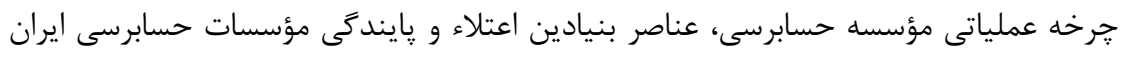

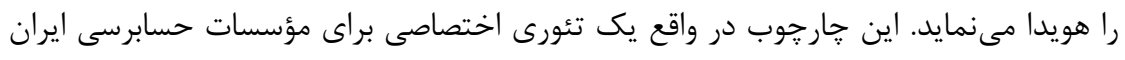

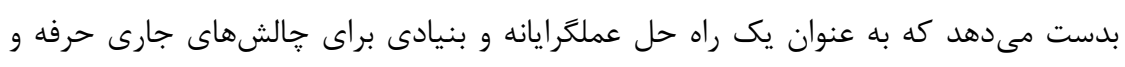


مؤسسات حسابرسى كشور از قبيل فقر و توسعهنيافتكى، ناكارايى قوانين و مقررات حرفه، از هم

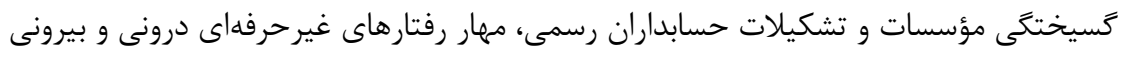
و تأمين انتظارهاى ذينفعان مثمرثمر است.

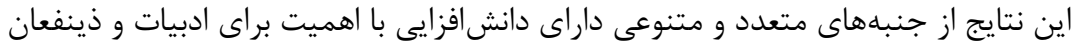

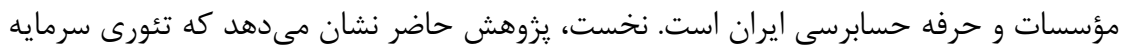

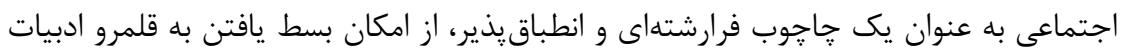

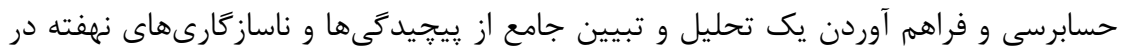

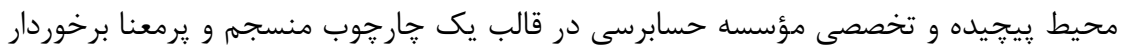

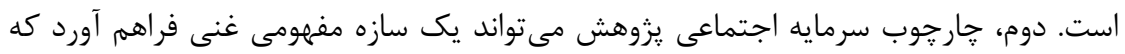

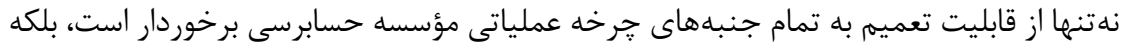

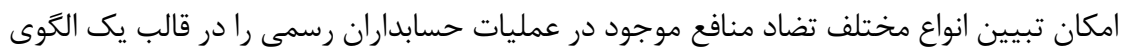

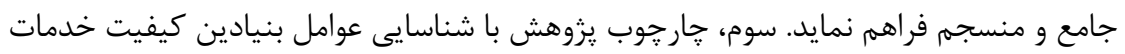

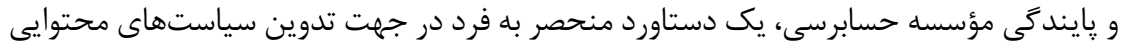

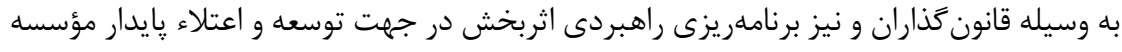

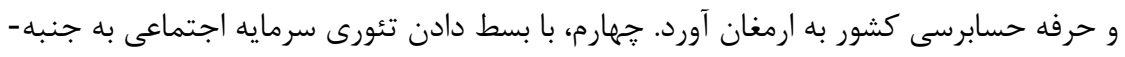

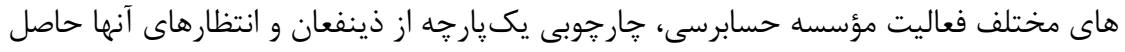

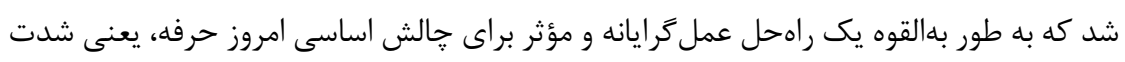

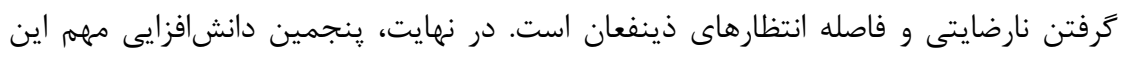
يزوهش شناسايى و طبقهبندى طيفى وسيعى از عناصر رفتارى مهمه و بنيادى در كيفيت و

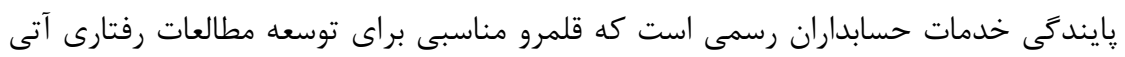

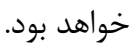

V- تقدير، تشكر و ملاحظات اخلاقى

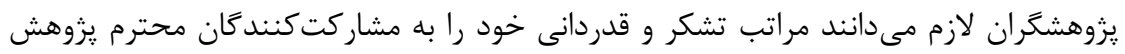

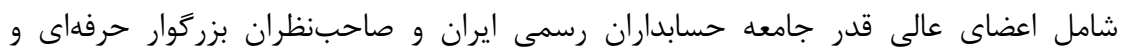

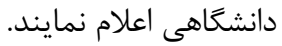




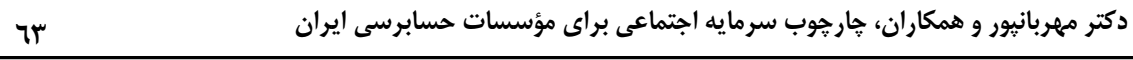

$$
\begin{aligned}
& \text { فهرست منابع احمدى لوبه، } \\
& \text { احمدى لويه، افشين؛ نيكومرام، هاشم؛ رهنماى روديشتى، فريدون و بنى مهل، بهمن. (1) (IVY)، }
\end{aligned}
$$

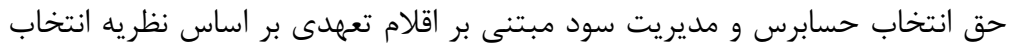

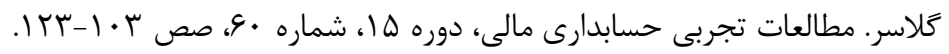

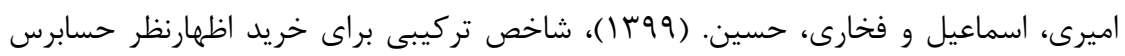

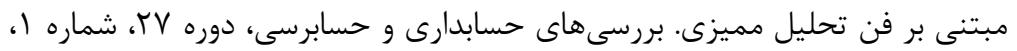

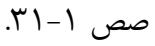

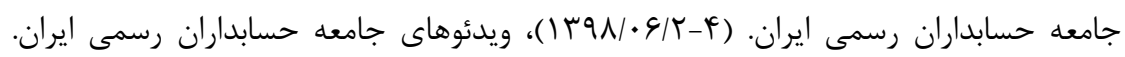

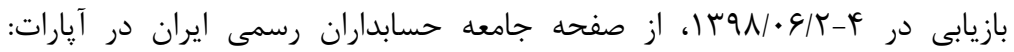

$$
\begin{aligned}
& \text { https://www.aparat.com/video/video/listuser/username/iacpa/w } \\
& \text { rapper/true } / \% \mathrm{D} 9 \% 87 \% \mathrm{D} 9 \% 85 \% \mathrm{D} 9 \% 87 \_\% \mathrm{D} 9 \% 88 \% \mathrm{DB} \% 8 \mathrm{C} \\
& \text { \%D8\%AF\%DB\%8C\%D9\%88\%D9\%87\%D8\%A7 }
\end{aligned}
$$

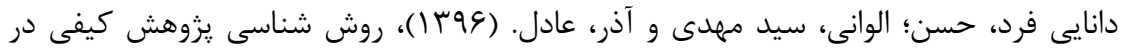

$$
\begin{aligned}
& \text { مديريت: رويكردى جامع. تهران: صفار. }
\end{aligned}
$$

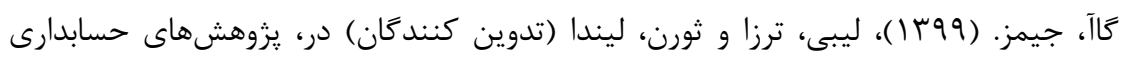

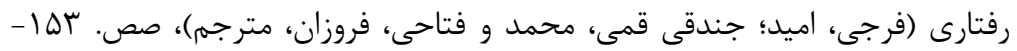

$$
\begin{aligned}
& \text { (IVF }
\end{aligned}
$$

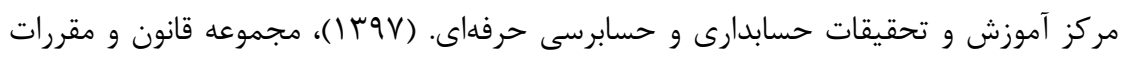

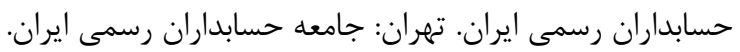

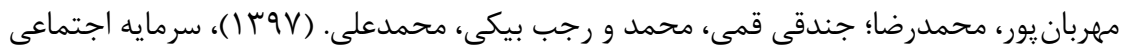

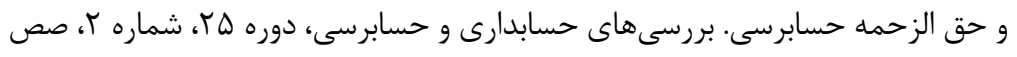

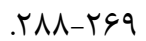

$$
\begin{aligned}
& \text { مهربانيور، محمدرضا؛ كرمى، غلامرضا و جندقى قمى، محمد. (99 (1)، تحليل SWOT برايل }
\end{aligned}
$$

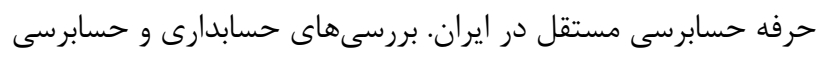

DOI: 10.22059/acctgrev.2020.290832.1008290

Adler, R., and G. Liyanarachchi. 2020. Towards measuring professionalism in accounting. Accounting \& Finance 60(3): 19071941.

Andiola, L. M., D. H. Downey, and K. D. Westermann. 2020. Examining climate and culture in audit firms: Insights, practice implications, 
دو فصلنامه حسابدارى ارزشى و رفتارى، سال ينجم، شماره دهم، پإييز و زمستان و9؟1

and future research directions. Auditing: A Journal of Practice \& Theory 39(4): 1-29.

Aobdia, D. 2020. The economic consequences of audit firms' quality control system deficiencies. Management Science 66(7): 28832905.

Bergner, J., B. B. Marquardt, and P. Mohapatra. 2020. The auditor reputation cycle: A synthesis of the literature. International Journal of Auditing 24(2): 292-319.

Bianchi, P. A., N. Carrera, and M. Trombetta. 2020. The effects of auditor social and human capital on auditor compensation: Evidence from the Italian small audit firm market. European Accounting Review 29(4): 1-29.

Bills, K. L., C. Hayne, and S. E. Stein. 2018. A field study on small accounting firm membership in associations and networks: implications for audit quality. The Accounting Review 93(5): 7396.

Bullen, M. L., and E. G. Flamholtz. 1985. A theoretical and empirical investigation of job satisfaction and intended turnover in the large CPA firm. Accounting, Organizations and Society 10(3): 287-302.

Burke, J. J., R. Hoitash, U. Hoitash, and S. Xiao. 2020. The costs and benefits of retirement policies at u.s. audit firms. Working Paper. Available at SSRN 3559503.

Christensen, L. B., R. B. Johnson, and L. A. Turner. 2015. Research Methods, Design, and Analysis (12 ed.). Essex: Pearson Education Limited.

Chu, L., D. A. Simunic, M. Ye, and P. Zhang. 2018. Transaction costs and competition among audit firms in local. Journal of Accounting and Economics 65(1): 129-147.

Citron, D. B., and R. J. Taffler. 2001. Ethical behaviour in the U.K. audit profession: The case of the self-fulfilling prophecy under goingconcern uncertainties. Journal of Business Ethics 29: 353-363.

Coffee, J. C. 2019. Why do auditors fail? What might work? What won't? Accounting and Business Research 49(5): 540-561.

Dasgupta, P., and I. Serageldin. 2000. Social Capital: A Multifaceted Perspective. Washington, D.C.: The World Bank.

DeFond, M. L., and C. S. Lennox. 2011. The effect of SOX on small auditor exits and audit quality. Journal of Accounting and Economics 52(1): 21-40.

DeFond, M., and J. Zhang. 2014. A review of archival auditing research. Journal of Accounting and Economics 58(2-3): 275-326. 
دكتر مهربانيور و همكاران، خارجوب سرمايه اجتماعى براى مؤسسات حسابرسى ايران

Duff, A. 2016. Corporate social responsibility reporting in professional accounting firms. The British Accounting Review 48(1): 74-86.

Duff, A. 2017. Corporate social responsibility as a legitimacy maintenance strategy in the professional accountancy firm. The British Accounting Review 49(6): 513-531.

Ege, M., Y. H. Kim, and D. Wang. 2020. Do global audit firm networks apply consistent audit methodologies across jurisdictions? Evidence from financial reporting comparability. The Accounting Review 95(6): 151-179

Eschenbrenner, B., F. F. Nah, and V. R. Telaprolu. 2015. Efficacy of social media utilization by public accounting firms: findings and directions for future research. Journal of Information Systems 29(2): 5-21.

Finley, A. R., M. H. Kim, P. T. Lamoreaux, and C. S. Lennox. 2019. Employee movements from audit firms to audit clients. Contemporary Accounting Research 36(4): 1999-2034.

Fontaine, R., S. B. Letaifa and D. Herda. 2013. An interview study to understand the reasons clients change audit firms and the client's perceived value of the audit service. Current Issues in Auditing 7(1): A1-A14.

Fukuyama, F. 2001. Social capital, civil society and development. Third World Quarterly 22(1): 7-20.

Gannon, B., and J. Roberts. 2020. Social capital: Exploring the theory and empirical divide. Empirical Economics 58: 899-919.

Goddard, A. 2017. Grounded theory approach to accounting studies: Overview of principles, assumptions and methods. In Z. Hoque, L. D. Parker, M. A. Covaleski, \& K. Haynes (Eds.), The Routledge Companion to Qualitative Accounting Research Methods (pp. 91111). New York: Routledge.

Gunn, J. L., C. Li, L. Liao, J. Yang, and S. Zhou. 2019. Audit firms' corporate social responsibility activities and auditor reputation. Working Paper. Availavble at: http://www.rieb.kobeu.ac.jp/tjar/conference/10th/CF3_Chan\%20Li.pdf.

Hall, M., and D. Smith. 2009. Mentoring and turnover intentions in public accounting firms: A research note. Accounting, Organizations and Society 34(6-7): 695-704.

Häuberer, J. 2011. Social Capital Theory: Towards a Methodological Foundation. Heidelberg, Germany: Springer Fachmedien.

Hay, D., R. Baskerville, T. H. Qiu. 2007. The association between partnership financial integration and risky audit client 
دو فصلنامه حسابدارى ارزشى و رفتارى، سال ينجم، شماره دهم، پإييز و زمستان و9؟1

portfolios. Auditing: A Journal of Practice \& Theory 26(2): 5768.

Hay, D., W. R. Knechel, and M. Willekens. 2014. Introduction: The function of auditing. In D. Hay, W. R. Knechel, and M. Willekens (Eds.), The Routledge Companion to Auditing (pp. 1-9). New York: Routledge.

He, X., S. P. Kothari, T. Xiao, and L. Zuo. 2020. Industry-specific knowledge transfer in audit firms: Evidence from audit firm mergers in China. Working Paper. Available at: SSRN 3209590.

Hegazy, M., K. Hegazy, and M. Eldeeb. 2020. The balanced scorecard: Measures that drive performance evaluation in auditing firms. Journal of Accounting, Auditing \& Finance. Available at: DOI: $10.1177 / 0148558$ X20962915.

Herda, D. N., and J. J. Lavelle. 2012. The auditor-audit firm relationship and its effect on burnout and turnover intention. Accounting Horizons 26(4): 707-723.

Hoopes, J. L., K. J. Merkley, J. Pacelli, and J. H. Schroeder. 2018. Audit personnel salaries and audit quality. Review of Accounting Studies 23(3): 1196-1136.

Iyer, V. M., E. M. Bamber, and R. M. Barefield. 1997. Identification of accounting firm alumni with their former firm: Antecedents and outcome. Accounting, Organizations, and Society 22(3): 315-336.

Jenkins, J. G., D. R. Deis, J. C. Bedard, and M. B. Curtis. 2008. Accounting firm culture and governance: A research synthesis. Behavioral Research in Accounting 20(1): 45-74.

Jha, A., and Y. Chen. 2015. Audit fees and social capital. The Accounting Review 90(2): 611-639.

Kelton, A. S., and R. R. Pennington. 2020. If you Tweet, they will follow: CEO Tweets, social capital, and investor say-on-pay judgments. Journal of Information Systems 34(1): 105-122.

Knechel, W. R. 2016. Audit quality and regulation. International Journal of Auditing 20(3): 215-223.

Lennox, C. S., and C. W. Park. 2007. Audit firm appointments, audit firm alumni, and audit committee independence. Contemporary Accounting Research 24(1): 235-258.

Lennox, C., C. Wang, and X. Wu. 2020. Opening up the 'black box' of audit firms: The effects of audit partner ownership on audit adjustments. Journal of Accounting Research 58(5): 1299-1341. 
دكتر مهربانبور و همكاران، خارجوب سرمايه اجتماعى براى مؤسسات حسابر سى ايران

Lenz, H., and M. L. James. 2007. International audit firms as strategic networks - The evolution of global professional service firms. In W. A. Muller, and M. Bihn (Eds.), Economics and management of networks (pp. 367-392). New York: Physica-Verlag HD.

Mills, S. K., and M. S. Bettner. 1992. Ritual and confilict in the audit profession. Critical Perspectives on Accounting 3(2): 185-200.

Mohr, J., and R. Spekman. 1994. Characteristics of partnership success: Partnership attributes, communication behavior, and conflict resolution techniques. Strategic Management Journal 15(2): 135152.

Morrison, A. D., and W. J. Wilhelm, Jr. 2004. Partnership firms, reputation, and human capital. American Economic Review 94(5): 1682-1692.

Nahapiet, J., and S. Ghoshal. 1998. Social capital, intellectual capital, and the organizational advantage. The Academy of Management Review 23(2): 242-266.

Narayana, V. G. 1995. Moral hazard in repeated professional partnerships. Contemporary Accounting Research 11(2): 895-917.

Pennings, J. M., and K. Lee. 1999. Social capital of organization: Conceptualization, level of analysis, and performance implications. In R. T. Leenders, and S. M. Gabbay (Eds.), Corporate Social Capital and Liability. New York: Springer Science+Business Media.

Pittman, J., Qi, B., and G. Zhang. 2019. The importance of social capital to individual auditors. Working Paper. Available at: SSRN 3365474.

Porter, B. 2014. The audit expectation gap: A persistent but changing phenomenon. In D. Hay, W. R. Knechel, and M. Willekens (Eds.), The Routledge Companion to Auditing (pp. 43-53). New York: Routledge.

Putnam, R. D. 2000. Bowling Alone: The Collapse and Revival of American Community. New York: Simon Schuster.

Sweavey, S. E., and M. J. Imhof, and T. J. Westfall. 2018. Audit firms as networks of offices. Auditing: A Journal of Practice \& Theory 37(3): 211-242.

Tervo, W., L. M. Smith, and M. Pitman. 2014. Dysfunctional auditor behavior: The effects of tone at the top and supervisors' relationships. Research on Professional Responsibility and Ethics in Accounting 17: 47-77. 
Vandenhaute, M., K. Hardies, and D. Breesch. 2020. Professional and commercial incentives in audit firms: evidence on partner compensation. European Accounting Review 29(3): 1-34.

Wallace, P. 2009. Reasons women chartered accountants leave public accounting firms prior to achieving partnership status: A qualitative analysis. Canadian Journal of Administrative Sciences 26(3): 179-196.

Wilson, A. B., C. McNellis and C. K. Latham. 2018. Audit firm tenure, auditor familiarity, and trust: Effect on auditee whistleblowing reporting intentions. Journal of International Accounting 22(2): 113-130.

Wolk, H. I., J. L. Dodd, and J. J. Rozycki. 2017. Accounting Theory: Conceptual Issues in a Political and Economic Environment (9 ed.). Thousand Oaks, California: SAGE.

Yang, Z. 2013. Do political connections add value to audit firms? Evidence from IPO audits in China. Contemporary Accounting Research 30(3): 891-921. 